\title{
CERAMIC VENEERS ON TEETH WITH NON-CARIOUS CERVICAL LESIONS: CASE REPORT AND FINITE ELEMENT ANALYSIS
}

\author{
FACETAS CERÂMICAS EM DENTES COM LESÕES CERVICAIS NÃO-CARIOSAS: \\ RELATO DE CASO E ANÁLISE DE ELEMENTOS FINITOS
}

\author{
Ana Paula Rodrigues MAGALHÃES ${ }^{1}$; Paulo Vinícius SOARES ${ }^{2}$; \\ Alexandre Coelho MACHADO ${ }^{3}$; Daiana Sabrine PAULI ${ }^{1}$; \\ Marcelle Ignez dos Santos Moura FALEIROS ${ }^{1}$; Rafael Almeida DECURCIO ${ }^{1}$; \\ Paula de Carvalho CARDOSO ${ }^{1}$
}

1. Department of Restorative Dentistry, Brazilian Dental Association, Goiânia, GO, Brazil; 2. Department of Operative Dentistry and Dental Materials, School of Dentistry, Federal University of Uberlândia, Uberlândia, MG, Brazil; 3. NCCL Research Group, Technical Health School, Federal University of Uberlândia, Uberlândia, MG, Brazil.

anapaulardm@gmail.com

\begin{abstract}
On ceramic veneers rehabilitation, teeth with non-carious cervical lesions (NCCLs), especially premolars, are often involved. Preparation to remove deep NCCLs may lead to excessive wear and a less conservative approach, which goes against the current principles of minimal wear and maximum preservation. However, no evidence exists indicating which technique could avoid excessive wear during the dental preparation for veneers associated with NCCL. Thus, this study aimed to present an aesthetic treatment with ceramic veneers and follow-up of 24 months of a patient with various levels of NCCL severity; and to evaluate various wear protocols for dental veneers associated with NCCL via Finite Element Analysis (FEA) to guide and justify the clinical decision of the clinical case described. A 37-year-old male patient presented for treatment with wear on the anterior teeth and with NCCLs of various severity degrees on the posterior teeth. The treatment chosen was rehabilitation with ceramic veneers on teeth 15 to 25 . The best restorative approach for the NCCL teeth was evaluated via an FEA, simulating various protocols and lesion depths while also calculating the percentage of tooth structure loss. Restoring the premolar's deeper NCCL with a composite resin core, before a ceramic veneer impression, presented better mechanical behavior in FEA and less tooth wear. For the $1.0 \mathrm{~mm}$ NCCL, beveling the lesion promoted good stress distribution, less invasive wear and an easier clinical procedure, as it did not involve a previous restorative procedure. It could be concluded that the restorative decision for premolars with NCCLs that will receive veneers should consider the set biomechanical behavior and especially the tooth structure wear necessary. For the case report presented, after two years of follow-up, no changes from the immediate result were observed, indicating that the cause of the lesions was eliminated, and that the treatment was effective, at least in the short-term. For FEA analysis, restoring the deeper NCCL prior to ceramic veneer impression, presented better mechanical behavior and less tooth wear. For the $1.0 \mathrm{~mm}$ NCCL, beveling the margin of the lesion generated the same good results.
\end{abstract}

KEYWORDS: Tooth wear. Dental veneers. Finite element analysis.

\section{INTRODUCTION}

Non-carious cervical lesions (NCCL) are defined as a loss of dental hard tissue at the cemento-enamel junction not related to a carious process (CIEPLIK et al., 2017). They usually result from a multifactorial process associated with abrasive and/or biocorrosive mechanisms but also from occlusal stress when the action of paraaxial occlusal biomechanical loads promote loss of tooth structure (GRIPPO; SIMRING; COLEMAN, 2012; JAKUPOVIC et al., 2014; TEIXEIRA et al., 2018). These loads concentrate stress in the cervical region of the tooth and generate the NCCL (JAKUPOVIC et al., 2014).
The presence of NCCLs in the cervical area changes tooth geometry and may also interfere in the stress concentrations, distribution and intensity in the chewing process, tending to their evolution (REES; HAMMADEH, 2004). Mechanical abrasion and biocorrosion after dentin exposure can also speed up the NCCL's progression. Removing or controlling the etiological factors involved in the development of the NCCLs is a very important step on their treatment, and the most effective measure on preventing their recurrence (SAWLANI et al., 2016; SOUZA et al., 2017). However, restoring these NCCLs is also very important for protection against more severe wear, preventing dentin hypersensitivity, enhancing aesthetics and 
minimizing the damages to a tooth's biomechanical behavior (OGINNI; ADELEKE, 2014; SOARES et al., 2014a; SOARES et al., 2015; MACHADO et al., 2017). Nowadays, many patients have an aesthetic complaint associated with NCCLs, requiring a more complex restorative resolution.

The ceramic veneers have been widely applied for aesthetic rehabilitation in recent years (CALAMIA; CALAMIA, 2007; SOARES et al., 2014b; ARIF et al., 2019). The presence of NCCLs makes the luting line on the cervical margin more fragile, as there is little or no enamel on that area and adhesion will rely on dentin (PERDIGÃO et al., 2014; REIS et al., 2017). Besides, the decision to prepare to remove deep NCCLs may lead to excessive wear and a less conservative approach. This goes against current principles of minimal wear and maximum preservation in every restorative treatment, including with ceramics (DECURCIO et al., 2015). No evidence exists indicating which technique could better avoid invasive wear during the dental veneer preparation associated with NCCL: a composite resin filling under the veneer or simply filling the NCCL with resin luting cement and ceramic.

Due to the difficulty of analyzing this kind of restoration in clinical or laboratorial studies, a finite element analysis (FEA) could help detect stress concentration areas in each possible restorative approach and lead to a more certain clinical decision. Thus, this study aimed to present an aesthetic treatment and follow-up with ceramic veneers of a patient with various levels of NCCL severity; and to evaluate various wear protocols for dental veneers associated with NCCL via FEA to guide the clinical decision of the clinical case described. For the second purpose, the null hypothesis was that there is no difference among various restorative techniques proposed in FEA.

\section{MATERIAL AND METHODS}

\section{Finite Element Analysis}

An FEA was used to evaluate the effects of NCCL, the amount of dental wear and the restorative technique's methods on the pattern of stress distribution on premolars. A computerized and two-dimensional linear FEA simulated a sound tooth model with dental structures, including dentin, pulp, enamel, periodontal ligament, cortical bone and trabecular bone (SOARES et al., 2008). Thirteen models were created, simulating various clinical situations listed in Table 1 and represented in Figure 1.

Table 1. Description of the CAD models according to the characteristics of each restorative technique simulated

\begin{tabular}{llll}
\hline Groups & Lesion depth & Wear & Restorative technique \\
\hline S & Sound & No & No \\
SBV & Sound & Minimal wear & Veneer \\
SV & Sound & Conventional & Veneer \\
L1 & $1,0 \mathrm{~mm}$ & No & No \\
L1BV & $1,0 \mathrm{~mm}$ & Bevel on lesion angle and minimal & Veneer \\
L1V & $1,0 \mathrm{~mm}$ & wear & Veneer \\
L1IV & $1,0 \mathrm{~mm}$ & Invasive (involving lesion) & Veneer \\
L1CV & $1,0 \mathrm{~mm}$ & Bevel & Composite resin core + Veneer \\
L2 & $2,5 \mathrm{~mm}$ & No & No \\
L2BV & $2,5 \mathrm{~mm}$ & Bevel on lesion angle and minimal & Veneer \\
L2V & $2,5 \mathrm{~mm}$ & wear & Conventional \\
L2IV & $2,5 \mathrm{~mm}$ & Invasive (involving lesion) & Veneer \\
L2CV & $2,5 \mathrm{~mm}$ & Bevel & Composite resin core + Veneer \\
\hline
\end{tabular}



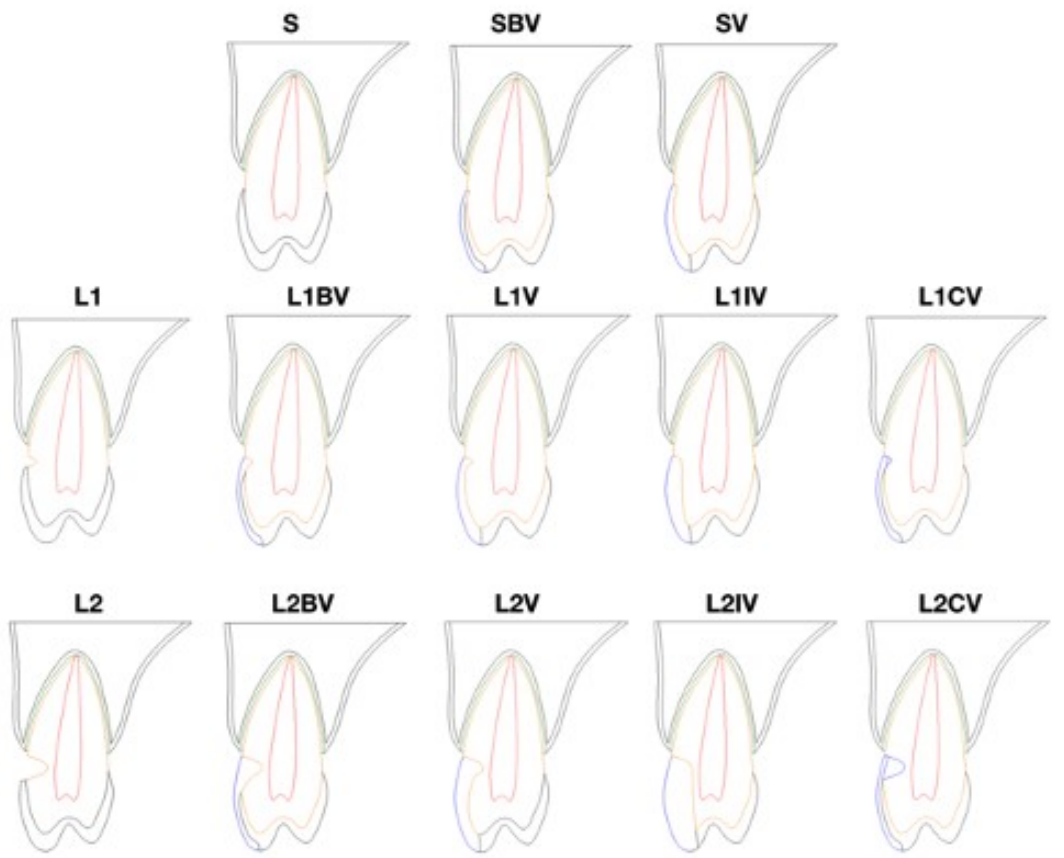

Figure 1. CAD models created according to the characteristics of each restorative technique simulated.

The dental structures' geometry was simulated using CAD Software (Rhino3D 4.0, Rhinoceros, United States) to obtain internal and external structural contours (Figure 2.A). This software also calculated the amount of tooth structure lost (enamel and dentin) in each simulated model as compared to the sound tooth. The models were exported to ANSYS 12.0 using the *. IGES format. The stress distribution patterns were analyzed using ANSYS 14.0 (Ansys Workbench 14.0, PA, United States). This software was used to define the dental structures' area (Figure 2.B), mechanical properties, mesh (Figure 2.C) and the boundary conditions of each model (Figure 2.D and 2.E) to produce the resulting analysis.
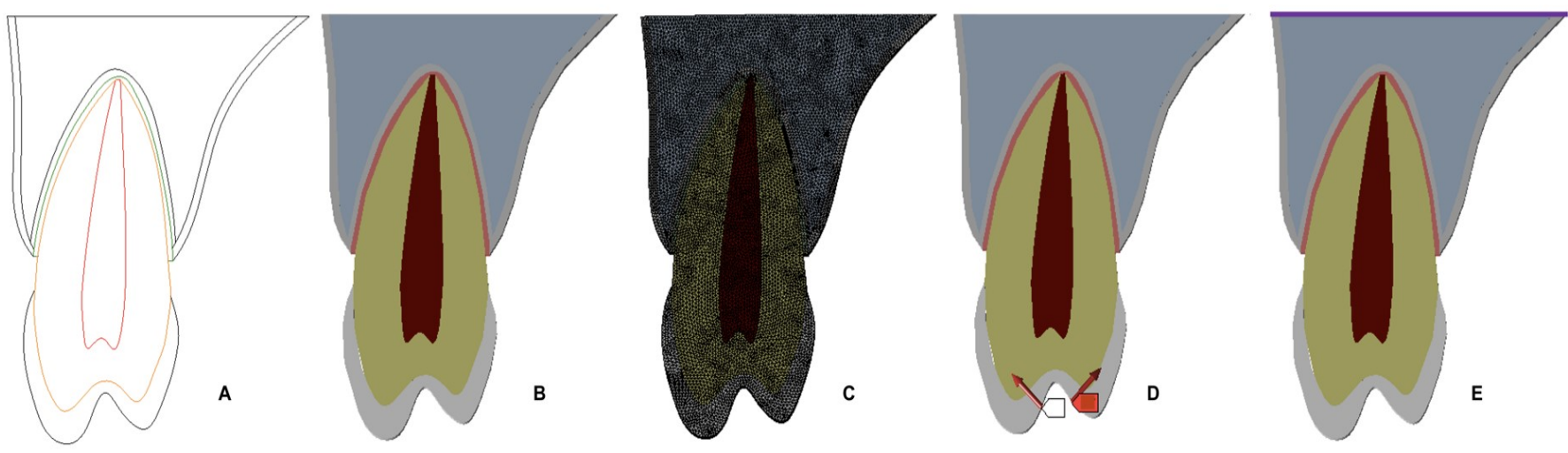

Figure 2. Finite Element models generation.

A) CAD software model outlines. B) Created areas of each dental and support structure. C) Mesh generation. D) Vertical loading applied (100N); E) Displacement restriction (null on the purple line).

Areas corresponding to each structure were plotted via linear associations (Figure 2.B). The models' mesh was elaborated using isoparametric elements of 8 - brick nodes with three degrees of freedom per node according to each structure's mechanical properties (Figure 2.C). The values for mechanical properties were obtained via literature review (Table 2). Enamel and dentine properties were considered orthotropic; other dental structural properties used were considered isotropic. The meshing process involved a division of the studied system into a set of small and discrete elements defined by nodes. The number of elements generated varied depending on the various 
geometries that were meshed, so the result accurately represented the original geometry. The models were considered homogeneous and elastic.

Table 2. Mechanical properties used for structures

\begin{tabular}{|c|c|c|c|}
\hline \multirow[t]{2}{*}{ STRUCTURE } & \multicolumn{3}{|c|}{ ORTHOTROPIC STRUCTURES (MIURA et al., 2009) } \\
\hline & Longitudinal & Transversal & $\mathrm{Z}$ \\
\hline & \multicolumn{3}{|c|}{ Young Modulus (MPa) } \\
\hline Enamel & 73720 & 63270 & 63270 \\
\hline Dentin & 17070 & 5610 & 5610 \\
\hline & \multicolumn{3}{|c|}{ Shear Coefficient (MPa) } \\
\hline Enamel & 20890 & 24070 & 20890 \\
\hline Dentin & 1700 & 6000 & 1700 \\
\hline & \multicolumn{3}{|c|}{ Poisson Ratio (v) } \\
\hline \multirow{4}{*}{$\begin{array}{c}\text { Enamel } \\
\text { Dentin } \\
\end{array}$} & 0.23 & 0.45 & 0.23 \\
\hline & 0.30 & 0.33 & 0.30 \\
\hline & \multicolumn{3}{|c|}{ ISOTROPIC PROPERTIES } \\
\hline & Elasticity Modulus (MPa) & \multicolumn{2}{|c|}{ Poisson Ratio (v) } \\
\hline $\begin{array}{c}\text { Composite Resin } \\
\text { (SHINYA et al., 2008) }\end{array}$ & 22000 & \multicolumn{2}{|c|}{0.27} \\
\hline $\begin{array}{c}\text { Cortical Bone } \\
\text { (CARTER; HAYES, 1977) }\end{array}$ & 13700 & \multicolumn{2}{|c|}{0.30} \\
\hline $\begin{array}{l}\text { Lithium Dissilicate (ERASLAN et } \\
\text { al., 2009) }\end{array}$ & 65000 & \multicolumn{2}{|c|}{0.23} \\
\hline $\begin{array}{c}\text { Medular Bone } \\
\text { (CARTER; HAYES, 1977) }\end{array}$ & 1370 & \multicolumn{2}{|c|}{0.30} \\
\hline $\begin{array}{l}\text { Periodontal Ligament } \\
\text { (MIURA et al., 2009) }\end{array}$ & 300 & \multicolumn{2}{|c|}{0.45} \\
\hline $\begin{array}{c}\text { Pulp } \\
\text { (RUBIN et al., 1983) }\end{array}$ & 2.07 & \multicolumn{2}{|c|}{0.45} \\
\hline
\end{tabular}

Each step of the boundary conditions included the displacement restrictions of the model and load application. The occlusal load $(100 \mathrm{~N})$ was applied equally on both cusps so that its resultant load was parallel to the tooth's long axis (Figure 2.D). The displacement model was restricted in all nodes on the cortical and medullar bone's base (Figure 2.E). The results of the mathematical calculations were plotted on the von Mises stress (equivalent stress) and the maximum principal stress, measured in MPa. The maximum principal stress was plotted without the restorative materials to better analyze the remaining tooth structure.

\section{RESULTS}

The von Mises stress and maximum principal stress patterns of all simulated models are presented in Figures 3 and 4, respectively.

For von Mises (Figure 3), the higher values (colors close to red) represent areas with higher stress and do not distinguish the stress type. The biomechanical behavior of the $\mathrm{S}$ model was similar to SBV and SV. These models presented more homogenous stress distribution compared to the models with NCCL (L1 and L2), independent of depth. With NCCL, the stress was concentrated at the bottom of the lesion, with greater stress on the $2.5 \mathrm{~mm}$ depth. Independently of the evaluated dental veneer preparation protocol associated with $1.0 \mathrm{~mm}$ NCCL, all models presented stress patterns closer to the sound tooth (S). For the models with $2.5 \mathrm{~mm}$ NCCL, the most invasive preparation (L2IV) showed greater stress values on the cavity preparation's dentin. The other models showed stress patterns similar to S, SBV and SV.

For maximum principal stress (Figure 4), the positive values (colors close to red and black) represent areas with greater tensile stress values, and the gray and white colors show regions without tensile stress. For this criterion, the tensile stress pattern was very close for all models, except for the situation with unrestored NCCL (for both 1.0 and $2.5 \mathrm{~mm}$ severities). 


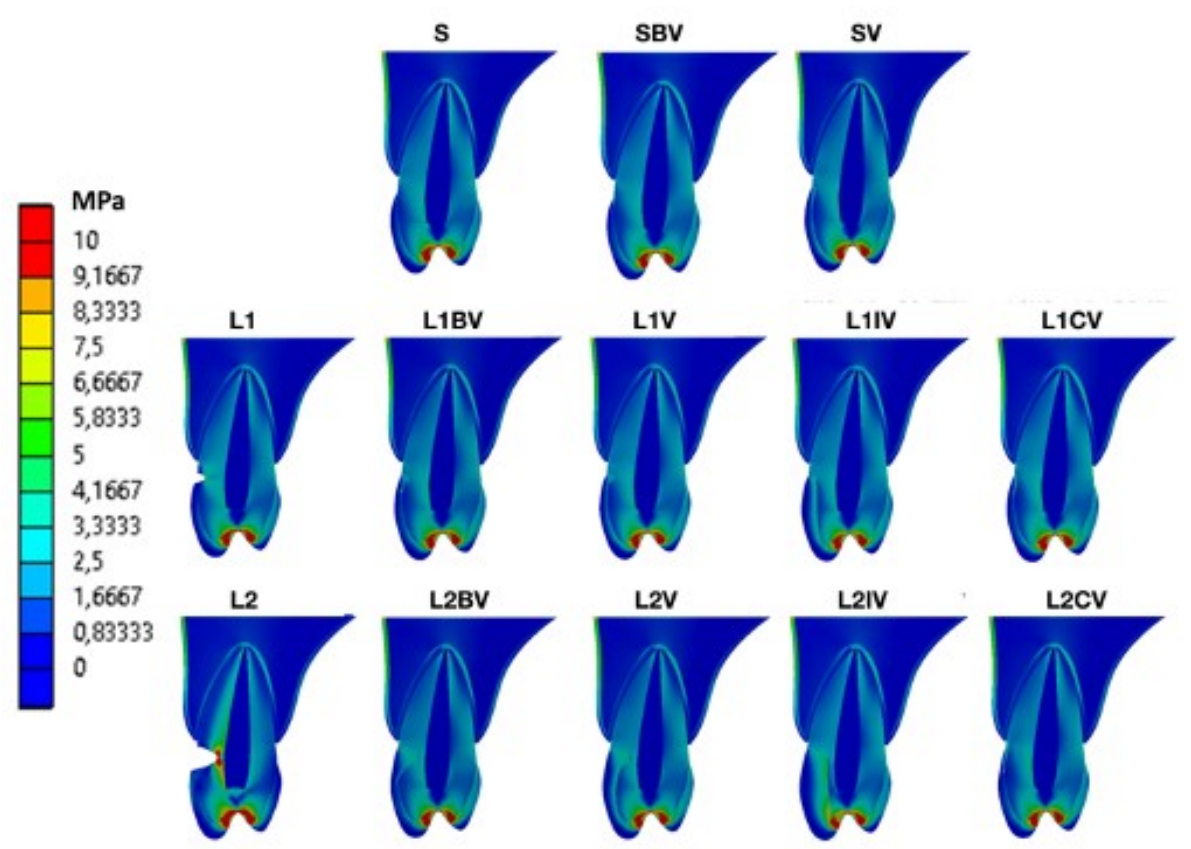

Figure 3. Stress distribution by von Mises criterion according to groups, identifying areas with higher stress (close to red color) and lower stress (close to blue color).
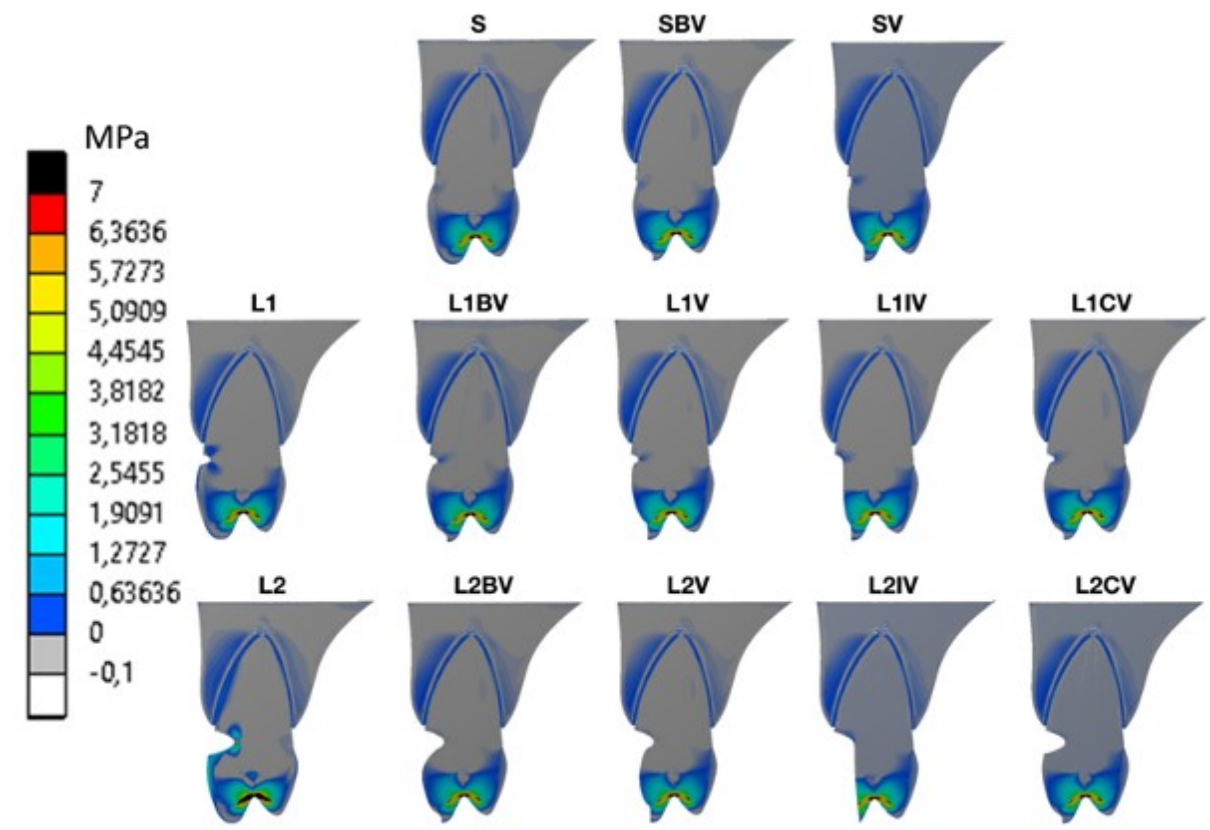

Figure 4. Stress distribution by maximum principal stress criterion according to groups, identifying areas with more tensile stress (red and black) and no tensile stress (gray and white).

Figure 5 shows the percentage of tooth area loss in each designed model compared with $\mathrm{S}$. Veneers on the sound tooth showed an enamel loss of $20.8 \%$ and $36.6 \%$ for minimal (SBV) and conventional veneers (SV) preparation, respectively. The amount of dentin loss for $1.0 \mathrm{~mm}$ NCCL and for veneer preparation was close (between $1.1 \%$ and $5.8 \%$ ) for all the restorative protocols evaluated. However, the enamel loss was $16.1 \%$ greater for conventional wear (L1V) than for the minimal wear
(L1BV) for $1.0 \mathrm{~mm}$ NCCL. The $2.5 \mathrm{~mm}$ lesion with conventional veneer wear (L2CV) presented enamel and dentin reductions up to $44.7 \%$ and $17.9 \%$, respectively. The model $\mathrm{L} 2 \mathrm{CV}$ with a $2.5 \mathrm{~mm}$ NCCL associated with composite resin core and veneer showed enamel loss similar to the SBV model with minimal veneer wear and dentin loss comparable to the L2 model (only for the $2.5 \mathrm{~mm}$ lesion). 


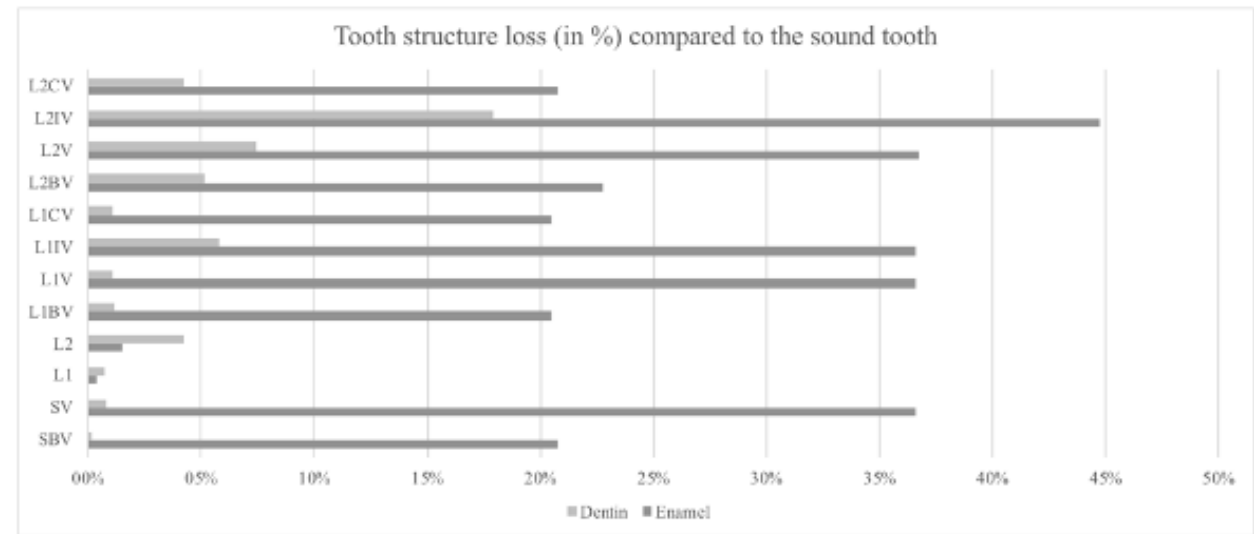

Figure 5. Tooth area loss (in \%) compared to the sound tooth for each NCCL or restorative technique model.

\section{Case report}

A 37-year-old male patient presented at the Restorative Dentistry clinic complaining that his smile looked aged and inverted (Figures 6 and 7). In resting-lips position, almost no tooth structure was visible (Figure 8). After clinical examination and a deeper anamnesis, he was noticeably unsatisfied with his smile due to significant tooth wear on the anterior teeth and the presence of NCCLs on the posterior teeth (Figure 9).

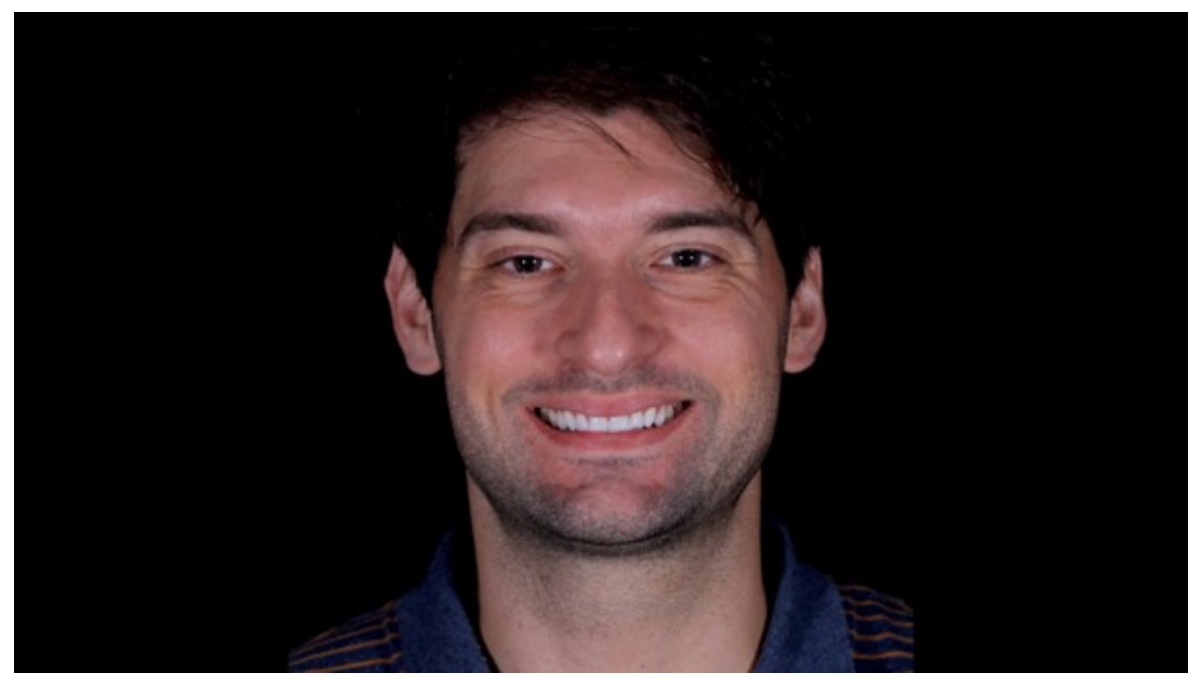

Figure 6. Initial smile picture of the patient.

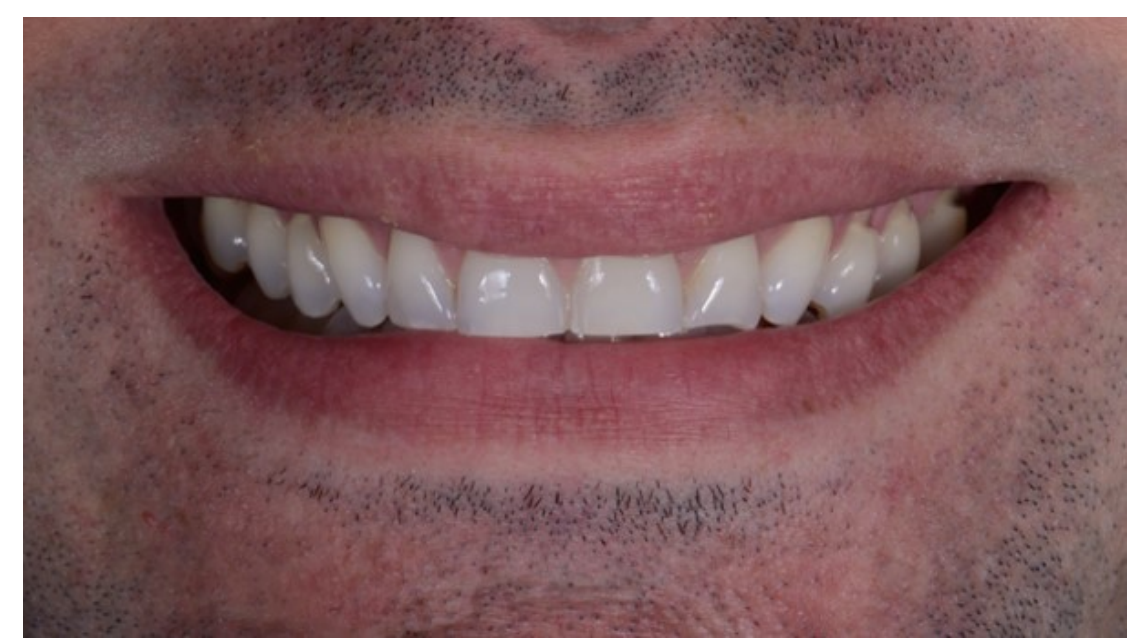

Figure 7. Inital smile, showing tooth wear. 


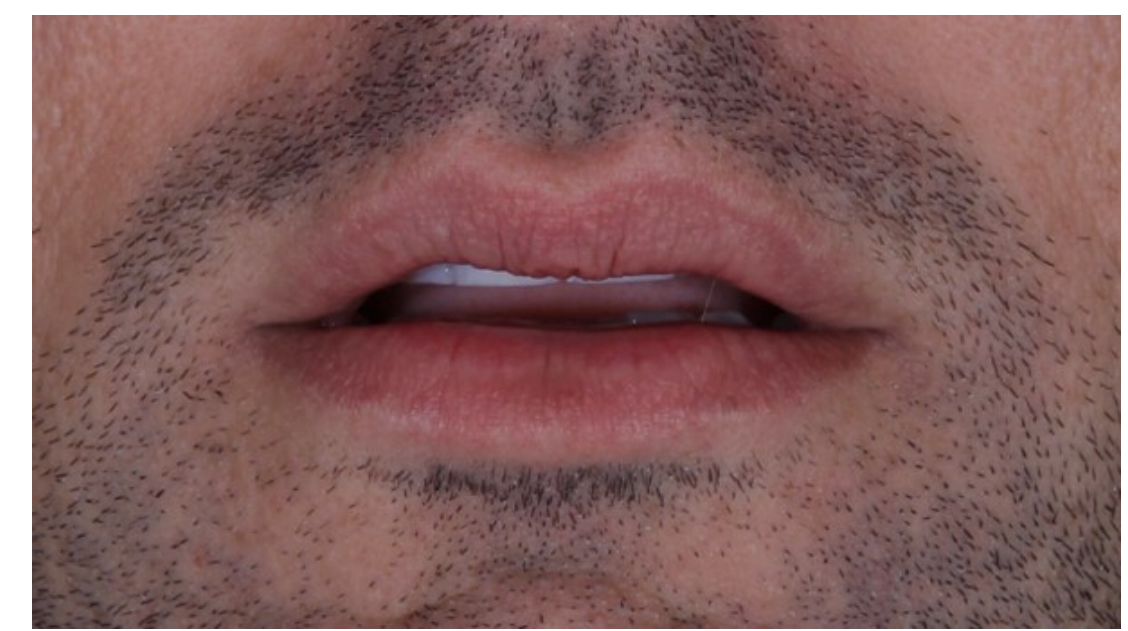

Figure 8. Resting-lips position photography showing insufficient teeth exposure.

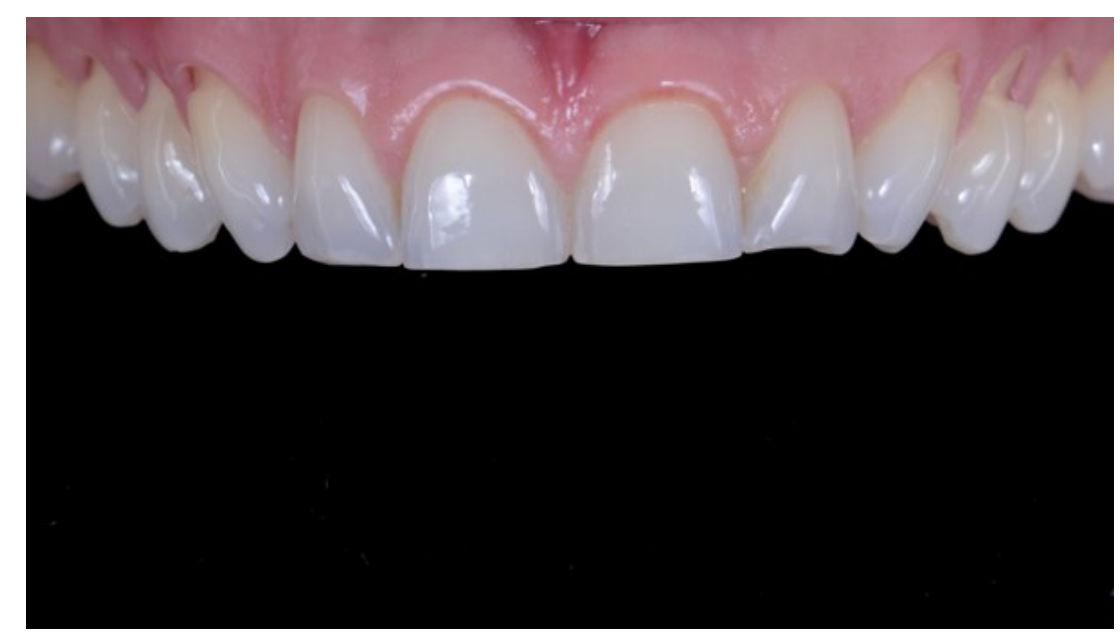

Figure 9. Intra-oral view evidencing anterior teeth wear and the presence of NCCLs in premolars and canines.

A close examination of his posterior teeth verified shallow NCCLs, mainly on teeth $13,15,23$, 25 and 26, and deeper NCCLs on teeth 14 and 24
(Figures 10 and 11). A periodontal probe (Golgran, São Caetano do Sul, Brazil) measured the NCCL on 24 as approximately $2 \mathrm{~mm}$ deep (Figure 12).

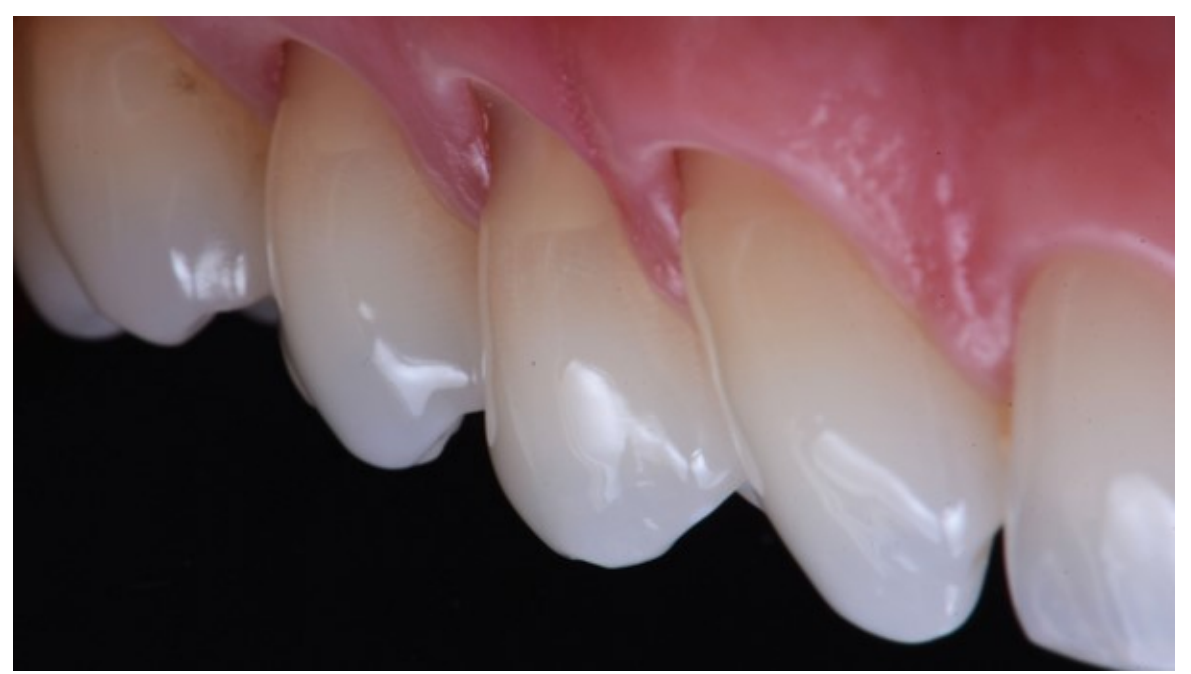

Figure 10. NCCLs of different depths in teeth 13, 14, and 15. 


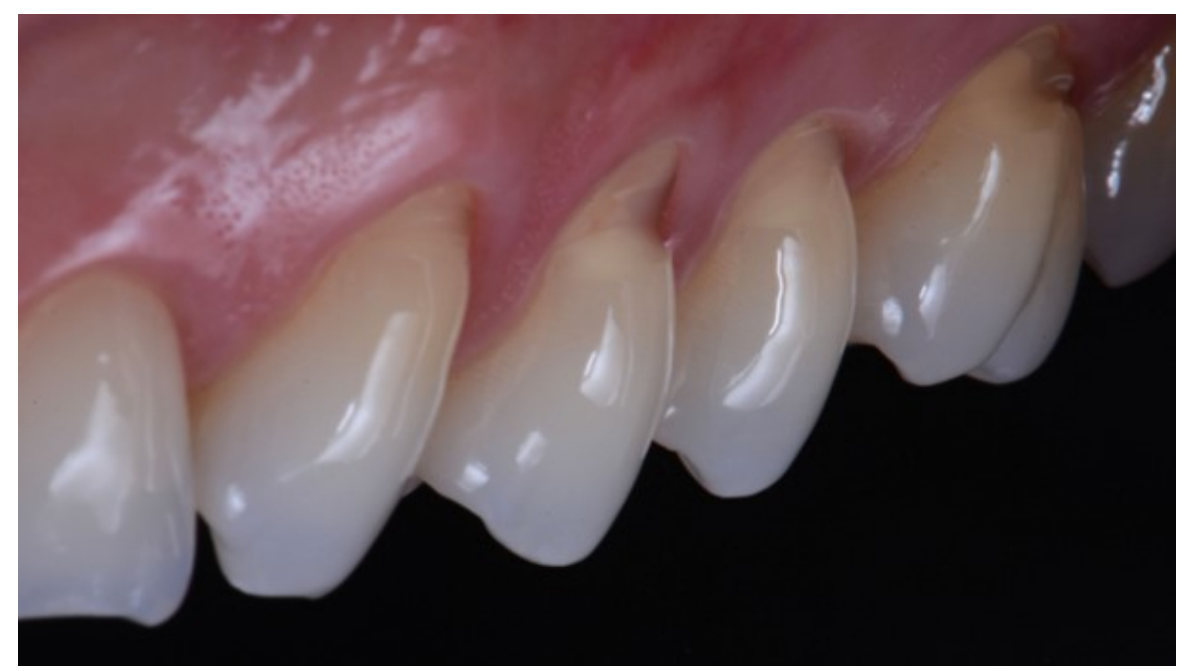

Figure 11. NCCLs of different depths in teeth 23, 24, 25, and 26.

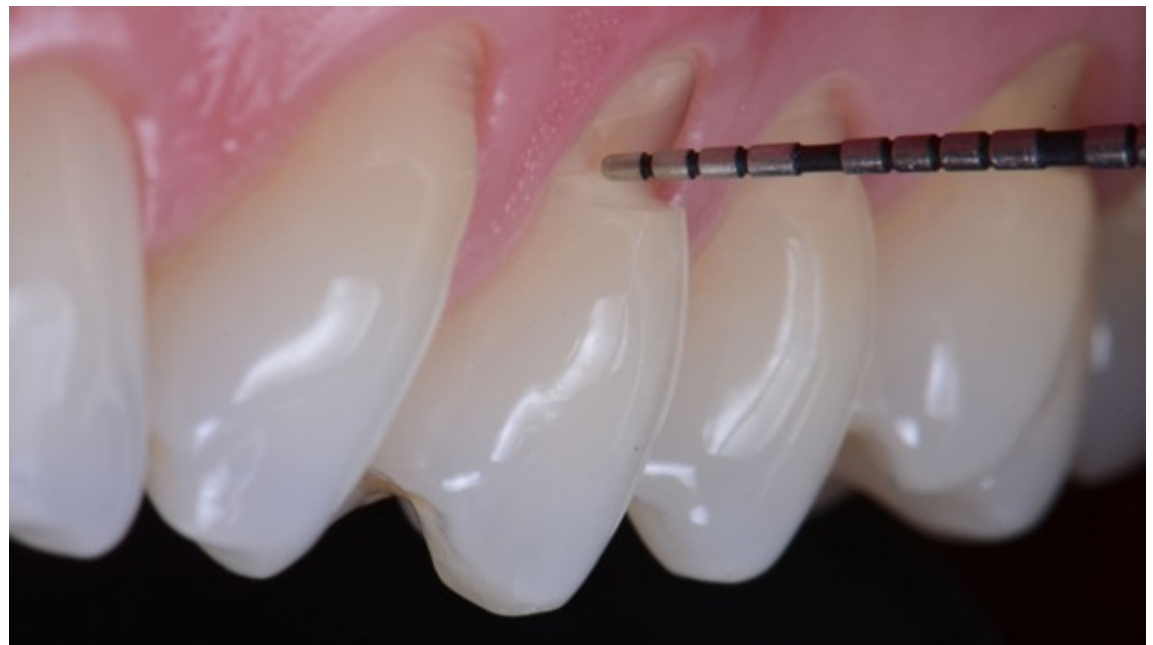

Figure 12. Periodontal probe measuring the approximately $2 \mathrm{~mm}$-depth NCCL in tooth 24.

In the interview, the patient reported that he presented bruxism for a while, which was probably the reason for all the wearing and could have helped develop the NCCLs he presented. The patient was further evaluated, and it was concluded that he no longer presented parafunctional habits. No premature contacts were identified in static occlusion, but occlusal interferences were found in the canine and anterior guides' disocclusion. No acid diet or reflux were identified. Reported dental hygiene habits did not justify the presence or depth of the NCCLs.

The patient presented a clear indication for aesthetic treatment with ceramic laminate veneers with minimal preparation. With the photographs taken, digital treatment planning was carried out to determine his ideal teeth dimensions. The reference for calculating dental size was the interpupillary distance (CESARIO; LATTA, 1984). Based on those calculations, a diagnostic wax-up was carried out for teeth 15 to 25 and a mock-up on bisacrylic resin (Protemp, 3M ESPE, Saint Paul, United
States) was obtained from the wax-up (Figures 13 and 14). With the mock-up in position, it was possible to see that the smile was no longer inverted and that the patient now had exposed teeth in resting-lips position. Also, the sizes calculated were harmonic to the patient's face and lips.

To improve the long-term life of the veneers, the preparations still had to be planned due to the presence of the NCCLs. No evidence exists in literature about what to do in these situations, although some evidence shows the biomechanical behavior of the tooth is better when the NCCL is restored (MACHADO et al., 2017).

After analyzing the FEA results, the clinical decision was to use the more conservative restorative techniques. The first step was to bevel the margins of the shallow NCCLs that were less than $1 \mathrm{~mm}$ deep. A diamond bur of extra-fine (FF) granulation (KG Sorensen, Cotia, Brazil) was used with slight pressure perpendicular to the enamel margin to round the NCCL angle, creating a bevel (Figures 15a-15c). 


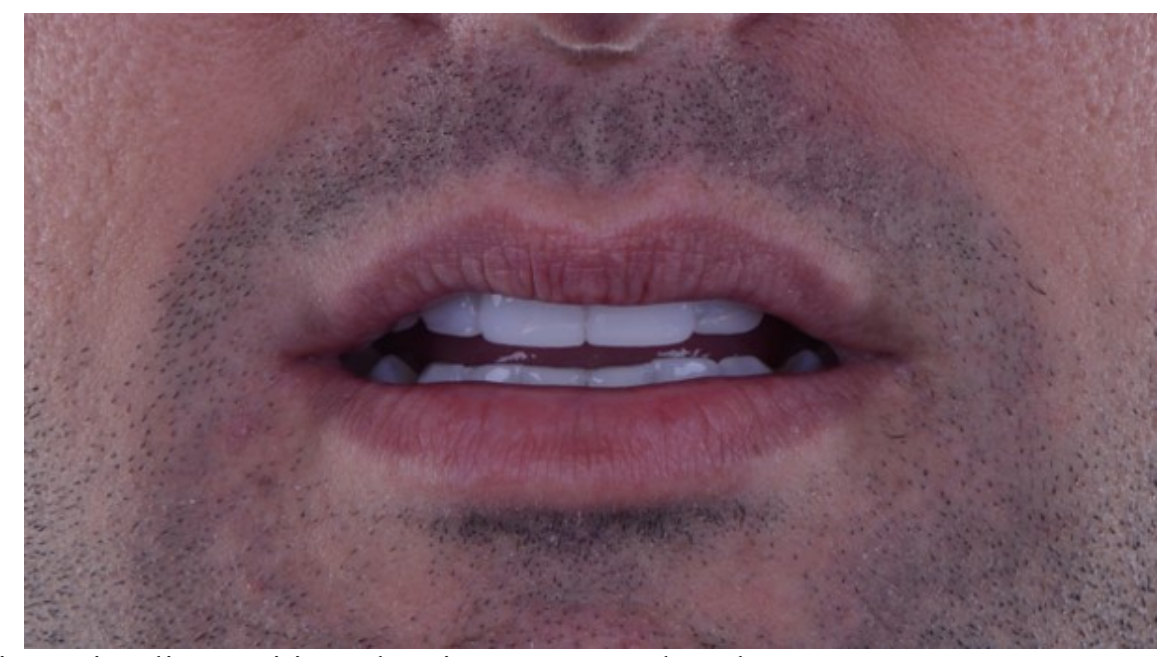

Figure 13. Mock-up in resting-lips position, showing, now, good teeth exposure.

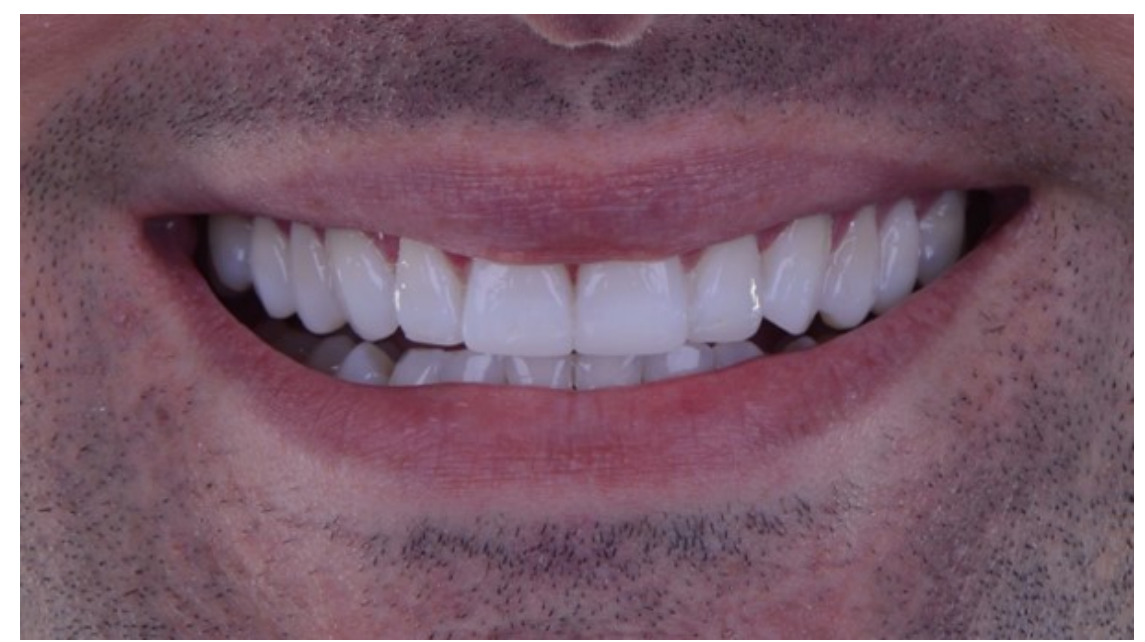

Figure 14. Smile with mock-up in position, rebuilding the worn teeth.

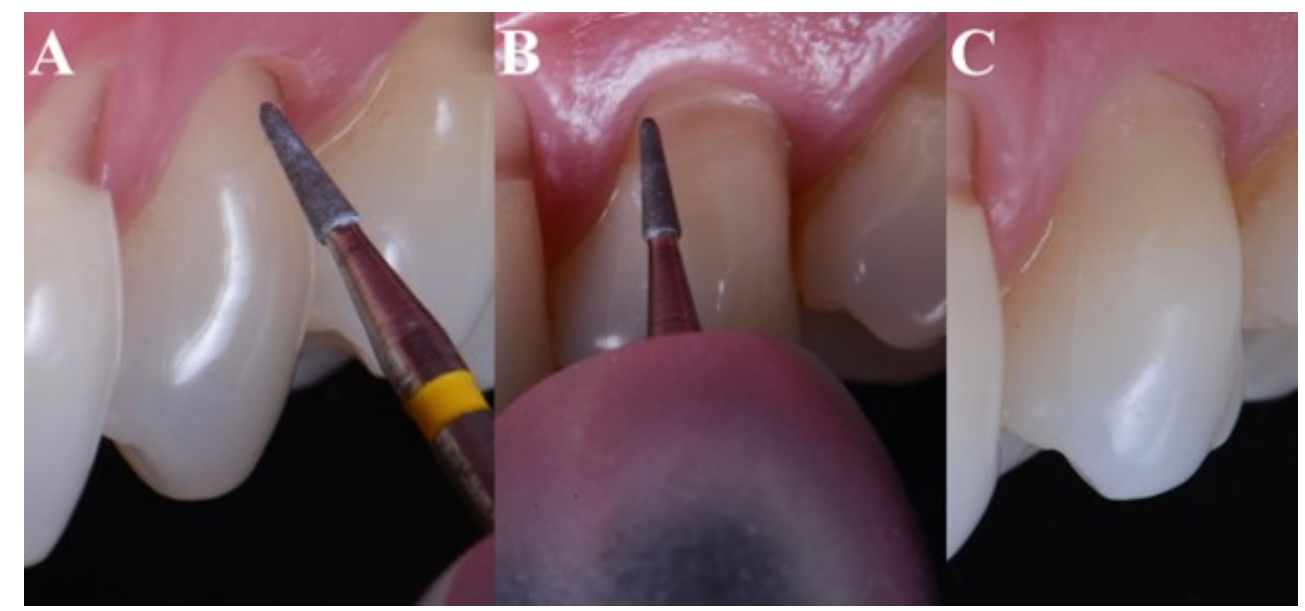

Figure 15. Clinical sequence for tooth 25(A and B), where only a bevel was created (C).

Then, lesions deeper than $2 \mathrm{~mm}$ were restored with composite resin prior to impression. It was impossible to carry out absolute field isolation on tooth 24 due to the lesion's subgingival depth. To control humidity, a relative isolation was carried out instead (DAUDT; LOPES; VIEIRA, 2013;
LOGUERCIO et al., 2015). First, the lip retractor, cotton rolls and saliva ejector were positioned (Expandex, Maquira, Maringá, Brazil), and a retractor cord (Ultrapack 00, Ultradent, South Jordan, United States) was carefully inserted in the gingival sulcus (Figures 16a and 16b). Selective 
enamel etching was carried out for 15 seconds with $37 \%$ phosphoric acid (Power Etching, BM4, Maringá, Brazil), and then the etching was washed for another 15 seconds (Figure 16c). Then, the adhesive Singlebond Universal (3M ESPE, Saint Paul, United States) was actively applied in one layer for 20 seconds (Figure 16d). The excesses were removed, and then the adhesive layer was light-cured for 10 seconds (Valo, Ultradent, South Jordan, United States) (Figure 16e). The composite resin (Filtek Z350 XT, 3M ESPE, Saint Paul, United
States) restoration was built in increments with spatulas (Golgran, São Caetano do Sul, Brazil) and brushes (Cosmedent, Chicago, United States) until the NCCL was completely filled (Figures 16f-16h). For tooth 14, absolute field isolation was carried out, and the same steps for restoring tooth 24 were carried out (Figures 17a-17b). Both restorations were polished with diamond burs (KG Sorensen, Cotia, Brazil) and rubber polishers (Cosmedent, Chicago, United States).

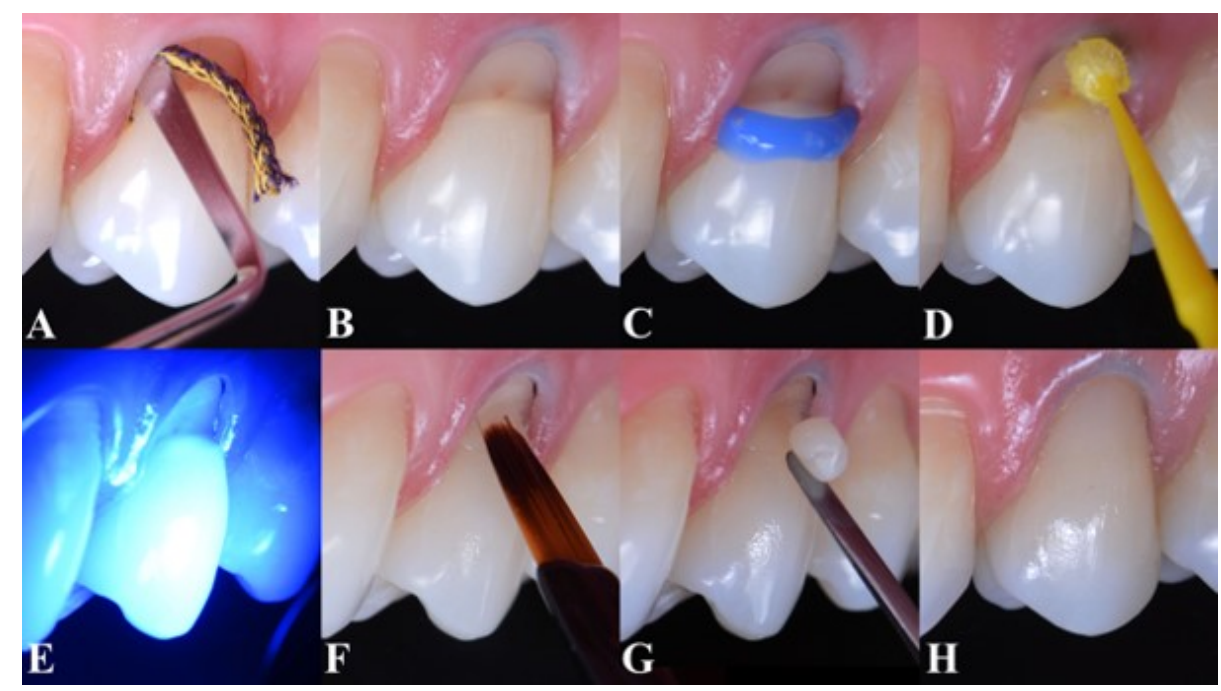

Figure 16. Clinical sequence for tooth 24: retractor cord insertion (A and B); selective enamel etching (C); universal adhesive application (D); photocuring $(\mathrm{E})$; incremental restorative technique $(\mathrm{F}$ and $\mathrm{G})$; and final composite resin restoration $(\mathrm{H})$.

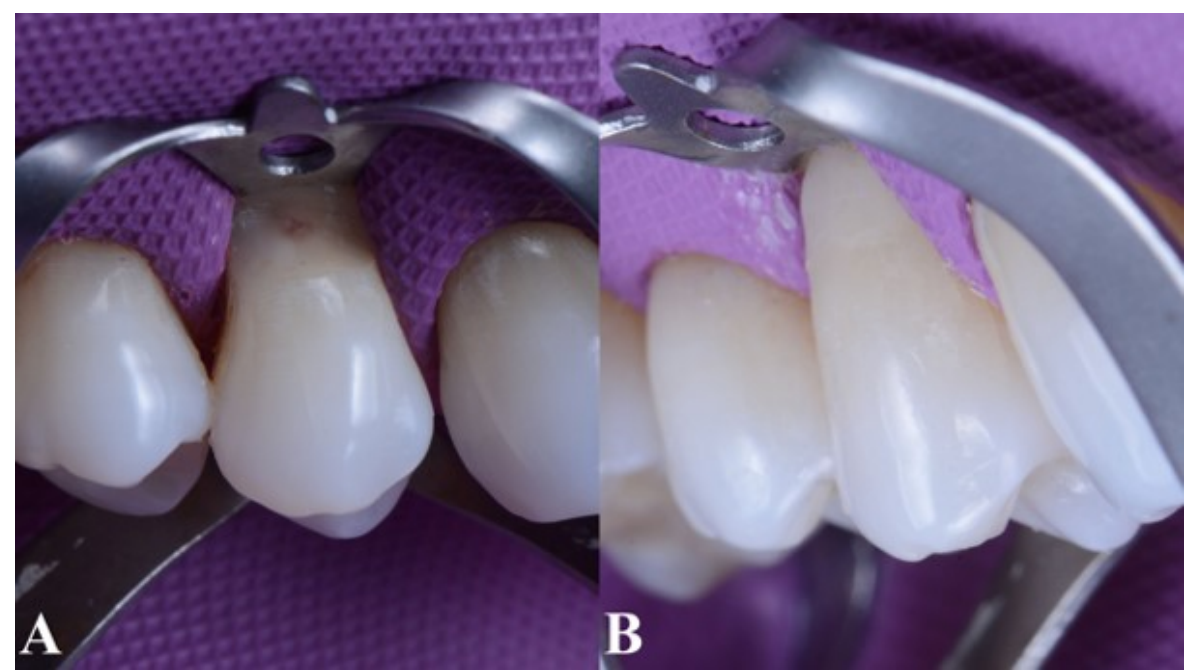

Figure 17. For tooth 14 it was possible to do absolute field isolation; initial NCCL aspect (A) and final restoration (B).

Then, minimal preparation was carried out on the other teeth, and impressions were taken using the two cords (Ultrapak, Ultradent) and two steps technique with addition silicon (Elite HD, Zhermack, Badia Polesine, Italy).

The obtained photographs, casts and occlusal registrations were sent to the technician to guide him through the presented clinical conditions for the development of the ceramic veneers. Considering the minimal preparation, no provisional restorations were needed. The ceramic veneers were made with lithium-disilicate ceramic (e.Max, 
Ivoclar Vivadent, Schaan, Liechtenstein) via the pressed technique and then painted to look more natural.

After cleaning the substrate with brushes (Microtuf, Hot Spot Design, Capão da Imbuia, Brazil), pumice stone (SS White, São Cristóvão, Brazil), and water, the veneers were positioned on the tooth's surface for adaptation and color evaluation with the try-in paste color Neutral (Variolink Esthetic, Ivoclar Vivadent, Schaan, Liechtenstein).

Then, the inner ceramic surface treatment was carried out with 5\% hydrofluoric acid (Power CEtching 5\%, BM4, Maringá, Brazil), respecting the 20-second conditioning time for lithium- disilicate. After that time, the acid was removed from the ceramic surface through an abundant water/air spray for residue removal (MAGALHÃES et al., 2017). This was followed by a silane application (Monobond Plus, Ivoclar Vivadent, Schaan, Liechtenstein). Then, after relative field isolation and protection of the neighboring teeth (Figure 18a), the enamel was etched with 37\% phosphoric acid (Power Etching ${ }^{\circledR} 37 \%$, BM4) (Figure 18b) for 30 seconds and then rinsed with water/air sprays for 30 seconds. The adhesive (Singlebond Universal, 3M ESPE) was actively applied to the enamel surface for 20 seconds, and excesses were removed (Figure 18c).

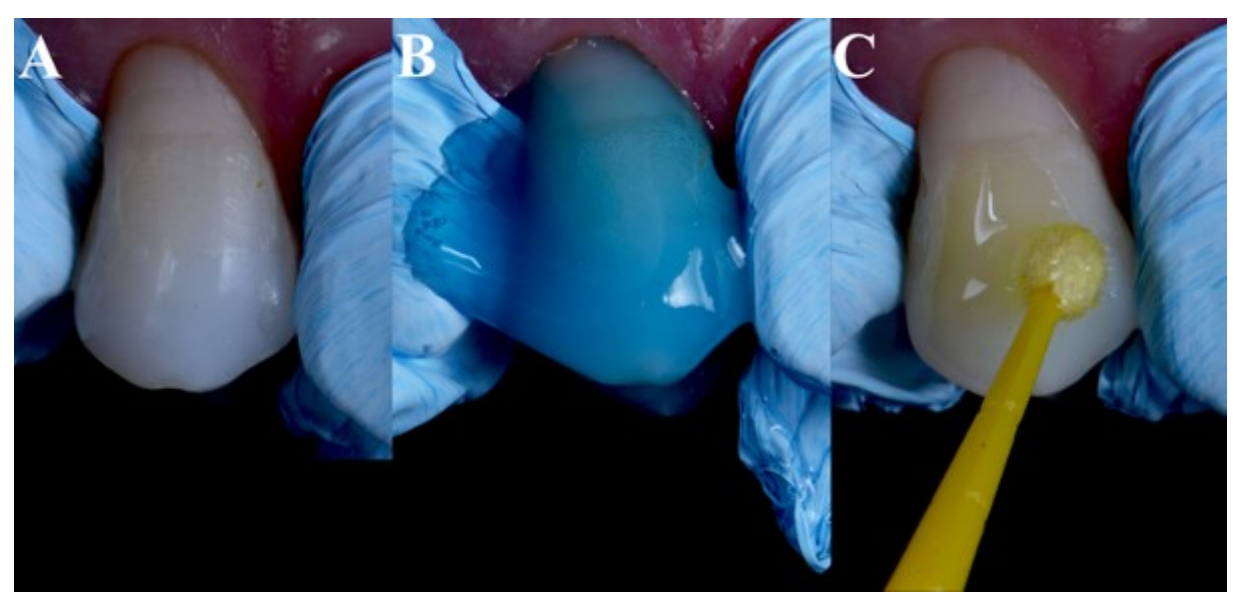

Figure 18. Luting of the veneer on tooth 14 with previous surface treatment: protection of the neighboring teeth (A); acid etching (B) and adhesive application (C).

Finally, the ceramic was filled with the light cured resin luting cement and the color selected in the trial stage (Variolink Esthetic Neutral, Ivoclar Vivadent). The veneer was positioned with continuous finger pressure (Figure 19). Then, the excesses were removed with a brush, and the veneer was light cured for 60 seconds in the buccal and palatal faces with poliwave light curing device (Valo, Ultradent). These procedures were repeated for each individual tooth. Those with shallow NCCLs with subgingival termination received a retractor cord (Ultrapak, Ultradent) before luting procedures, and then everything was carried out the same way (Figure 20a-20c and 21).

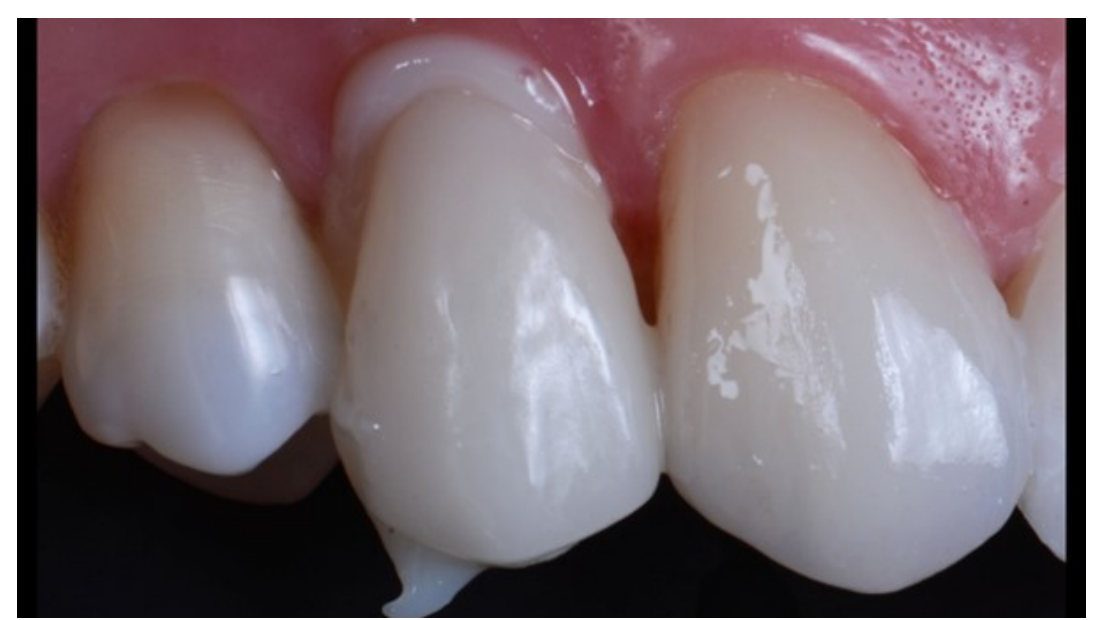

Figure 19. Ceramic veneer positioned on tooth 14 prior to cement excess removal and photocuring. 


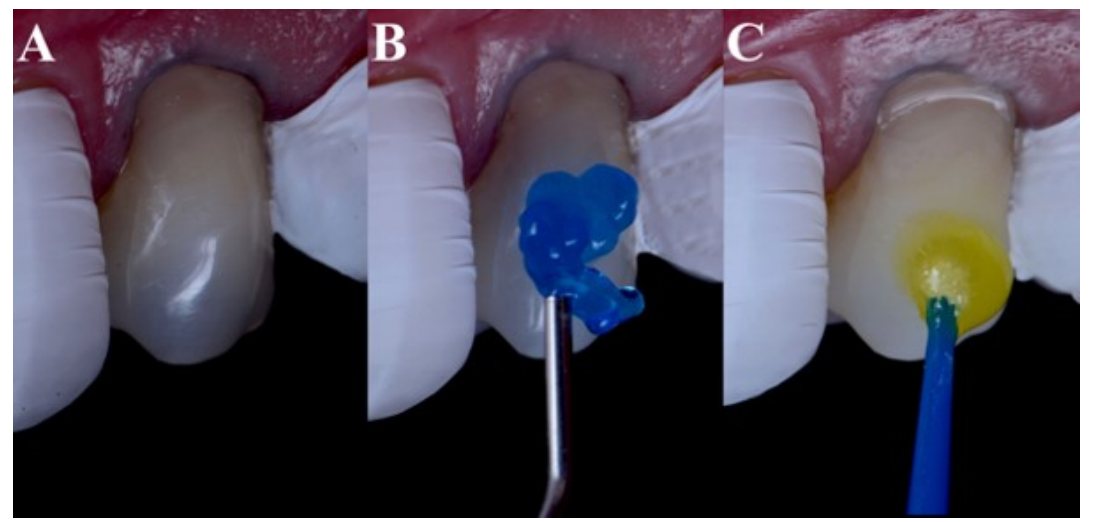

Figure 20. Luting of the veneer on tooth 25 with previous surface treatment: protection of the neighboring teeth (A); acid etching (B) and adhesive application (C).

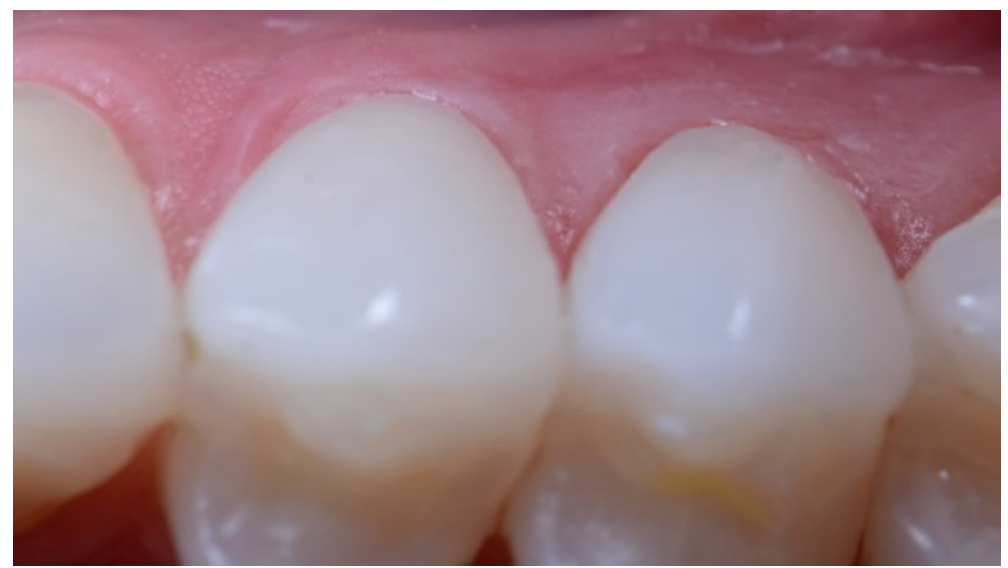

Figure 21. Luted veneers on teeth 24 and 25.

After luting, all the porcelain veneers were finished with a serrated saw strip (Komet, Lemgo, Germany) on the proximal areas and with scalpel blade n.12 (Solidor, Joinville, Brazil) in the cervical region to remove excesses. The occlusal adjustments were carefully carried out to reestablish his anterior and canine guides and balance his occlusal loads, especially on the teeth that presented NCCLs. In the next appointment, when complete elimination of cement excesses was confirmed, the margins were polished with abrasive silicones for ceramic polishing, the Porcelain Veneer $\mathrm{Kit}^{\circledR}$ (Shofu, Japan). Figures 22 to 24 show the final photos after cementation. No occlusal guard was installed as the patient did not present bruxism anymore by the time the treatment was carried out, and the excursive guides were reestablished properly. He was further oriented to execute good oral hygiene, brushing and flossing, and also to return to the dentist for prophylaxis every six months in order to detect any problems on the veneers as soon as possible.

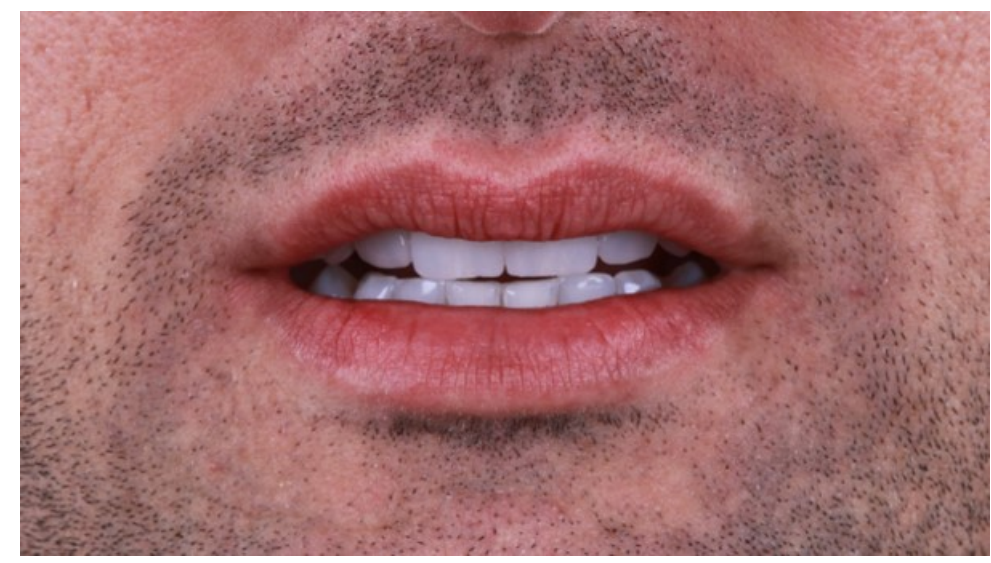

Figure 22. Final resting-lips position picture showing adequate tooth exposure. 


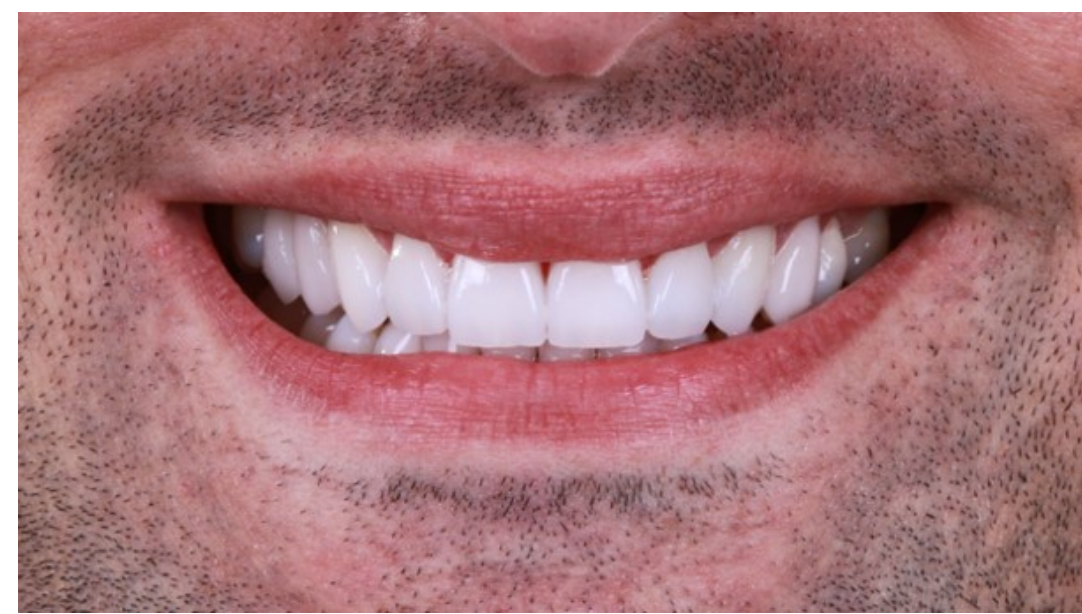

Figure 23. Final smile picture showing teeth compatible with the patient's age, without wear.

Figure 24. Final face smiling picture showing a harmonious smile.

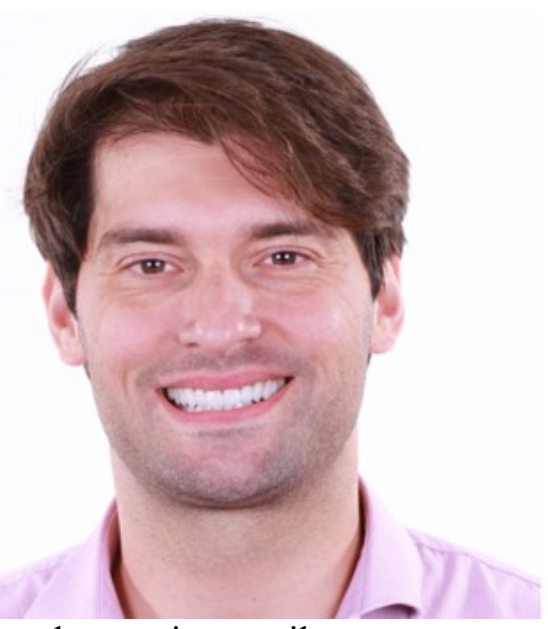

A year and, then, two years later, this patient returned for examinations. No changes were observed in teeth without NCCL or in those with shallow or deep lesions, and the patient declared himself satisfied with the treatment (Figures 25-28). These results may show that the cause of the lesions was eliminated, and that the treatment was effective, at least in the short-term.

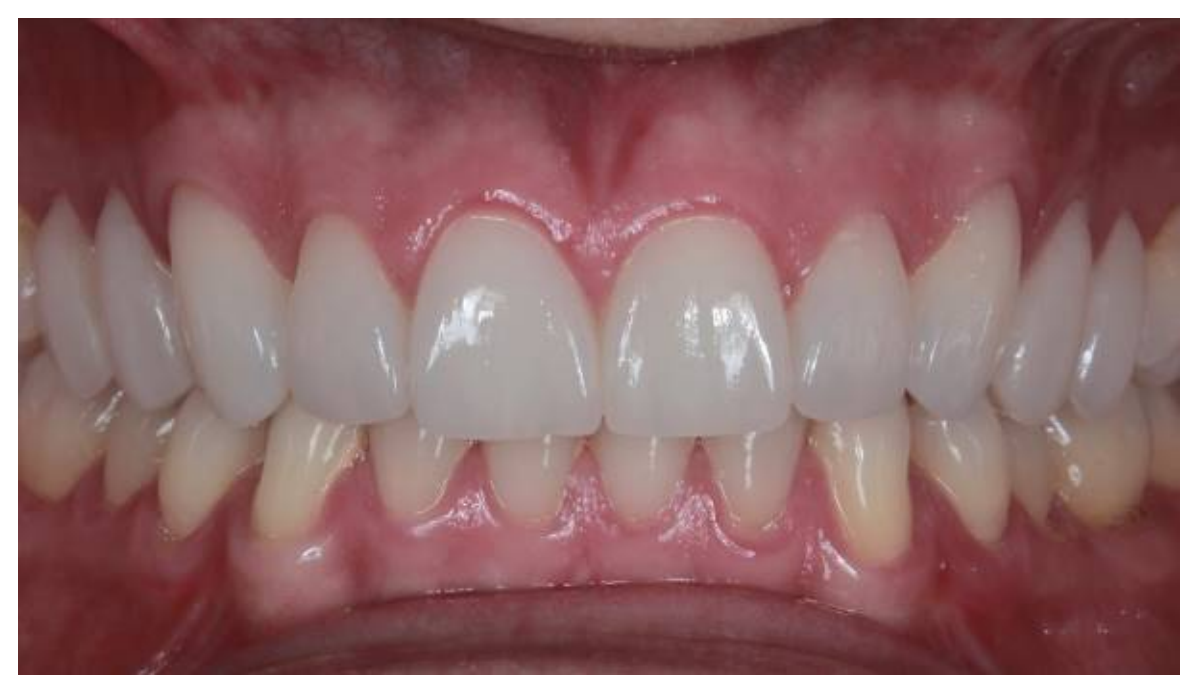

Figure 25. Two years follow up of the ceramic veneers. 


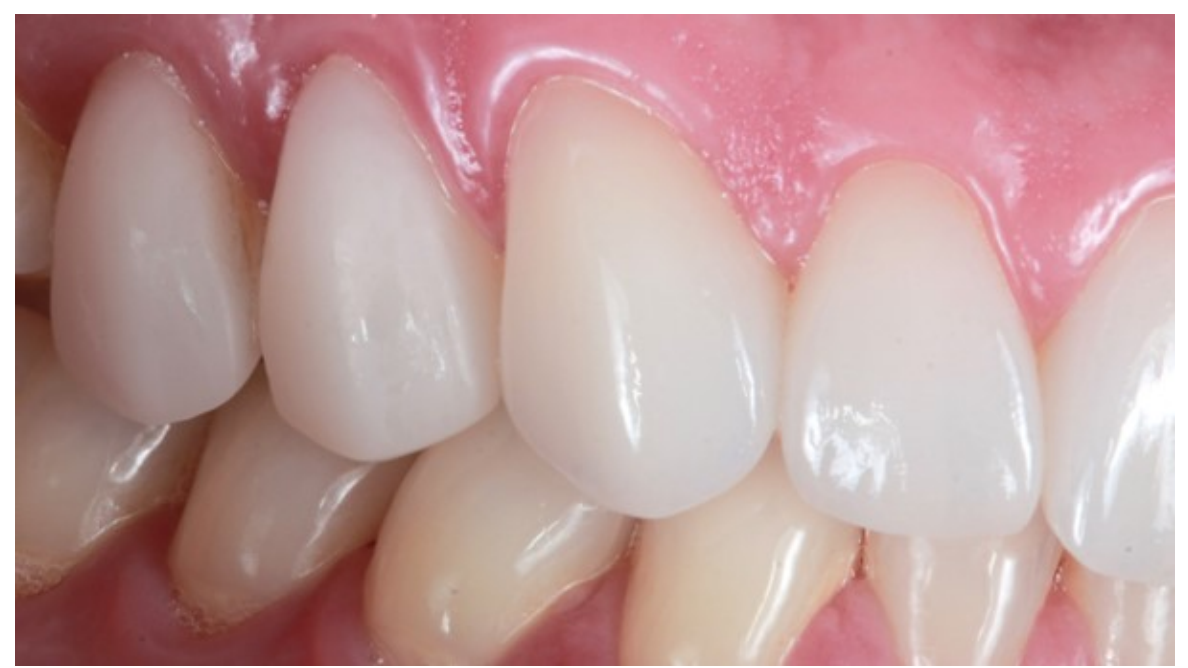

Figure 26. Close-up of teeth with previous NCCLs 13, 14, and 15, two years latter.

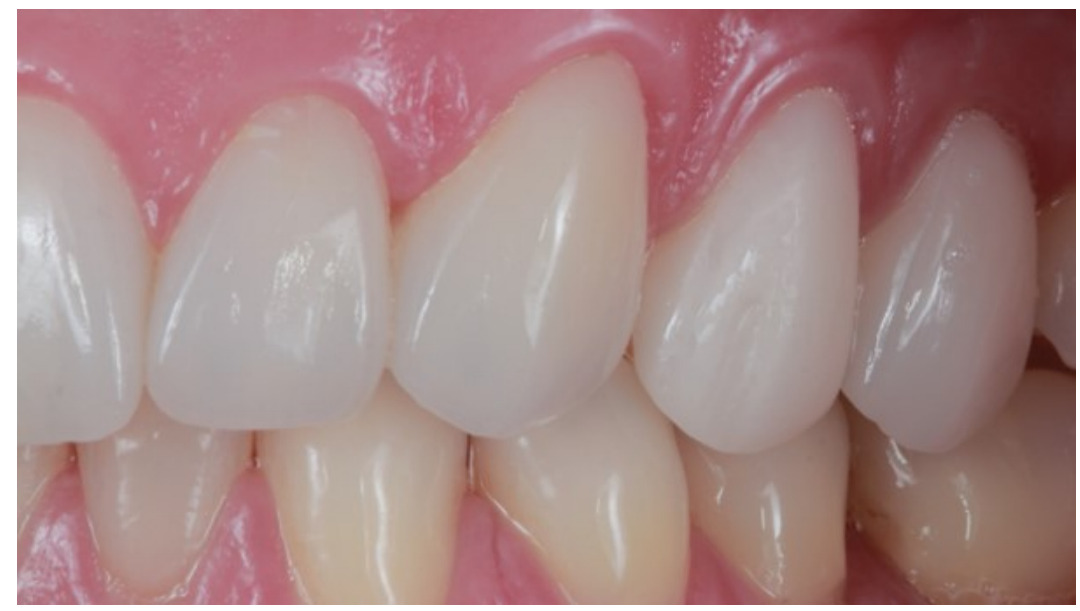

Figure 27. Close-up of teeth with previous NCCLs 23, 24, and 25, two years latter.

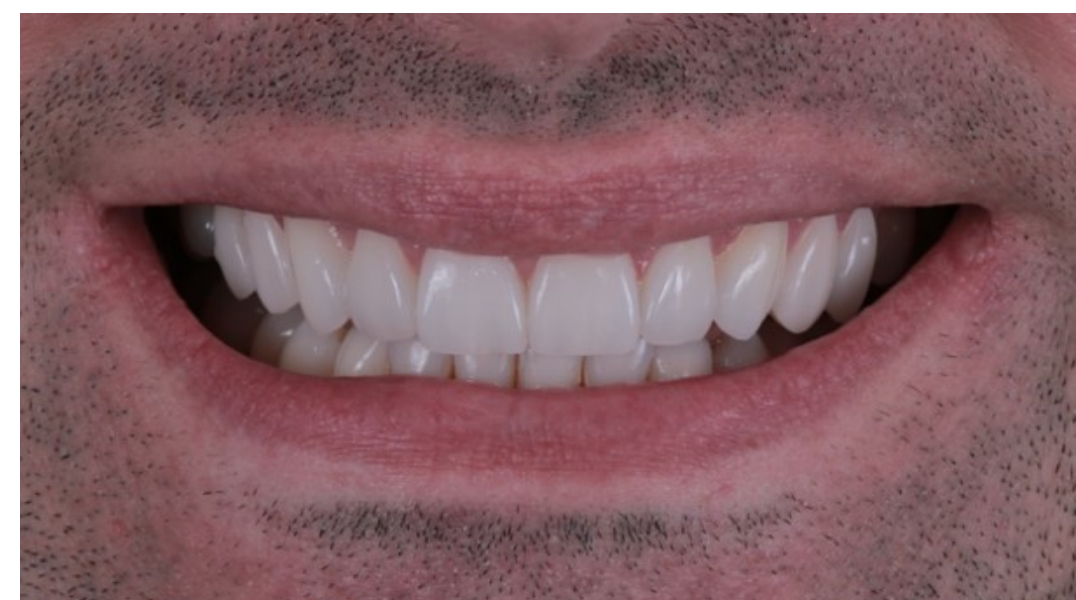

Figure 28. Patient smile after two years of the esthetic-functional treatment, with the veneers in very good conditions.

\section{DISCUSSION}

One origin of NCCLs is reported to be tooth deflection caused by excessive occlusal loads in lateral movements (POIATE et al., 2009). They are more frequently observed in upper premolars' buccal surfaces (SOARES et al., 2015; TEIXEIRA et al., 2018), as seen in the clinical case reported. The mean prevalence varies from 27 to $85 \%$ and increases with age (TANAKA et al., 2003). Enamel in the cervical region is very thin, formed by a few layers of enamel prisms. These layers cannot bear 
tensile stress, making this area more susceptible to NCCL formation (POIATE et al., 2009). This loss of dental structure in NCCLs, though lower than 5\% (Figure 16), causes great changes in the dental components' biomechanics. Thus, they must be restored to reestablish the mechanical balance and avoid NCCL progression (SOARES et al., 2015; SOARES; GRIPPO, 2017). Other factors could also relate to the formation of NCCLs, including age, gender, gastric diseases, brushing teeth, exogenous acid agents and more (SOUZA et al., 2017; TEIXEIRA et al., 2018).

There is a consensus that NCCLs should be restored with adhesive materials with optical properties similar to the tooth (KIM et al., 2009; MACHADO et al., 2017), as they improve aesthetics and can minimize hypersensitivity (SOARES et al., 2008; FRON et al., 2011; CHEE; RICKMAN; SATTERTHWAITE, 2012; REIS et al., 2017; TEIXEIRA et al., 2018). If the restorative material presents mechanical properties similar to the tooth's properties, it may also restore the biomechanical balance lost with the NCCL formation. Dental materials with mechanical properties much higher or lower than those of the tooth structure may lead to stress concentration and deformation in the affected area (MACHADO et al., 2017). However, few studies analyze some possible restorative protocols for NCCLs (MACHADO et al., 2017).

FEA is a widely used numerical analysis that has been successfully applied in many areas of engineering and bioengineering since 1950 (SOARES et al., 2012). Today, it is considered one of the broadest available methods to calculate the complex conditions of stress distribution in dental systems (VERSLUIS; TANTBIROJN, 2009). Thus, FEA makes it possible to analyze stresses observed in various clinical situations that could not be simulated in laboratory studies or evaluated clinically. It is possible to define the areas of stress concentration and the ones more likely to fail within a structure or material (SOARES et al., 2008; SOARES et al., 2012).

Cases like the one presented are very common nowadays, as many patients suffer from occlusal disorders and may develop NCCLs in teeth under these occlusal forces (SAWLANI et al., 2016). Another indicator of occlusal disorder in this case is the wear observed in the anterior teeth. The patient did not present alteration on the occlusal dimension, so the aesthetic rehabilitation with veneers was enough to solve his complaint and to rebuild the anterior guides, but it had to be planned correctly to avoid invasive preparations and unwanted tooth structure sacrifice, especially in the teeth with NCCLs.

Considering the restorative material, composite resins are widely used to restore NCCLs because they do not require excessive wear, have a Young modulus comparable to dentin, a micromechanic retention by adhesion to the tooth structure and a good aesthetic (FERRACANE, 2011; DEMARCO et al., 2017). Ceramic materials also present characteristics that justify their use in restoring NCCLs (MACHADO et al., 2017). For example, they conduct heat and electricity poorly, show little degradation from abrasion or biocorrosion, adhere to a tooth's structure via a resin cement, and are excellent for polishing (MCCABE; WALLS, 2008). However, they present high flexural strength and Young modulus, making their mechanical behavior similar to enamel but very different from dentin (MCCABE; WALLS, 2008). Thus, an interesting restorative approach would be to use composites to replace dentin and use ceramics to replace enamel (MACHADO et al., 2017).

When analyzing the FEA results, all the studied restorative approaches presented a biomechanical behavior similar to the sound tooth model, except for the L2IV model, which presented higher stresses in dentin on the von Mises criteria; rejecting the null hypothesis. This occurred mainly because the occlusal load was applied parallel to the tooth's long axis, which corresponds to the best mechanical behavior of every tooth element. Other occlusal loads were not studied, as the authors assumed that veneers should not be placed in situations of unbalanced occlusions or in the presence of occlusal interferences. During the clinical function, occlusal interferences and higher magnitudes of occlusal forces could enhance the risk of rupture, anticipating the failure of the ceramic veneer, either on the resin cement interface or on ceramic (ARCHANGELO et al., 2011).

Considering the similar biomechanical behavior, the choice of restorative technique should consider the FEA results and, most importantly, the preservation of tooth structure. The determination of the NCCL depth was important in order to decide for the best treatment indication, as differences were observed in the FEA analysis and also in the volume of tooth structure loss for the different approaches studied (ZEOLA et al., 2016). For the $1.0 \mathrm{~mm}$ lesion, the beveled model and the composite resin core models made it possible to save more tooth structure when compared to the other wear designs. Considering the difficulty of restoring this kind of lesion, especially due to location and humidity, a more practical clinical procedure would be to bevel 
the NCCL. As there was no difference in biomechanical behavior or tooth structure loss, the bevel and minimal wear seems to be the most appropriate approach for this severity of NCCL, and this approach was chosen for the presented clinical case.

Restoring the $2.5 \mathrm{~mm}$ NCCL with a composite resin core prior to veneer luting promotes more homogenous stress distribution (MACHADO et al., 2017). In this case, as previously discussed, the composite resin could mimic the mechanical behavior of dentin because ceramic played the role of enamel, resulting in a stress distribution very similar to a sound tooth (MACHADO et al., 2017). Furthermore, this approach could save more healthy dental structure, even when compared to the beveled model, and avoid a more invasive wear. Thus, that was the chosen restorative strategy for the case presented and may be the more appropriate clinical decision for such lesions.

In this strategy, questions may be raised considering the ceramic luting over the composite resin core. Studies show that the bond strength between the core material and the resin cement is usually good, even when aging of the composite is carried out (GRESNIGT et al., 2012; POLAT et al., 2015). Polat et al (2015) in their study, showed that the best surface treatment for the aged core composite, previous to luting, was Er:YAG laser irradiation. Although, 35\% phosphoric acid etching led to bond strength values statistically similar to that of non-aged composite (control group). Another study evaluating the influence of proximal box elevation on the bond strength of composite inlays, showed that the presence of composite did not affect the results for a total etch resin cement (DA SILVA GONÇALVES et al., 2017). The same authors showed that the composite presence actually improved adhesion for a self-adhesive cement (DA SILVA GONÇALVES et al., 2017), supporting the use of the composite resin core for NCCL situations as well.

The presence of a traumatic occlusion by nonaxial loads of occlusal interferences is considered a very important factor in the occurrence and development of abfractions (SAWLANI et al., 2016). Thus, irrespective of the type of restoration performed, the removal of possible occlusal interferences and the reestablishment of occlusal balance are very important for stopping NCCLs' development and avoiding the appearance of new lesions after treatment (SOARES et al., 2015). Possible biocorrosive or abrasive causes that might have led to the NCCLs should also be controlled to ensure a long-lasting treatment (SOARES et al., 2015).

Ceramic veneers presented high survival rates of almost $100 \%$ from 7 to 14 years (D'ARCANGELO et al., 2012; ARIF et al., 2019). The clinical behavior after two years is an important indicator of the short-term behavior of the treatment proposed, as many failures can be observed in the first months of follow-up (D'ARCANGELO et al., 2012). The absence of new NCCLs, of ceramic fractures, chipping or staining shows that probably the NCCLs' etiologic factors were adequately controlled. A longer observation period is necessary in order to verify the true effectiveness of the treatment proposed, specially the importance of the differentiation of deeper and shallower NCCLs.

This study is limited as it presents results of one clinical case in the short term and a nondestructive evaluating method (FEA), that considers homogeneous and static models, that do not represent the actual clinical situation. However, it presents a new approach for more complex evaluations in the area. Further clinical studies with the variables determined in this work should be carried out to further elucidate the subject.

\section{CONCLUSIONS}

The restorative decision for premolars with NCCLs that are going to receive veneers should consider the biomechanical behavior and, especially, the necessary tooth structure wear.

For the case report presented, after two years of follow-up, no changes from the immediate result were observed, indicating that the cause of the lesions was eliminated, and that the treatment was effective, at least in the short-term.

Restoring the premolar's deeper NCCL with a composite resin core, prior to ceramic veneer impression, presented better mechanical behavior in FEA and less tooth wear. For the $1.0 \mathrm{~mm}$ NCCL, beveling the lesion promoted good stress distribution, less invasive wear and an easier clinical procedure because it did not involve a restorative procedure.

RESUMO: Na reabilitação com facetas cerâmicas, dentes com lesões cervicais não cariosas (LCNC), especialmente pré-molares, estão frequentemente envolvidos. O preparo para remover a LCNC pode levar a um desgaste excessivo e a uma abordagem menos conservadora, o que vai contra os princípios atuais de mínimo 
desgaste e máxima preservação. Entretanto, não existem evidências indicando qual técnica pode evitar o desgaste excessivo durante o preparo para facetas associado com LCNC. Portanto, esse artigo tem dois objetivos principais: 1) apresentar um tratamento estético com facetas cerâmicas e acompanhamento de 24 meses de um paciente com vários níveis de severidade de LCNC e 2) avaliar vários protocolos de preparo para facetas cerâmicas associadas com LCNC por meio do Método de Elementos Finitos (MEF) para guiar e justificar a decisão clínica do caso clínico descrito. Um paciente de 37 anos, gênero masculino, compareceu para tratamento com desgaste nos dentes anteriores e com LCNC com vários graus de severidade nos dentes posteriores. Optou-se pela reabilitação com facetas cerâmicas nos dentes 15 a 25. A melhor abordagem restauradora para os dentes com LCNC foi avaliada por MEF, simulando vários protocolos e profundidades de lesão, além disso foi calculada a porcentagem de estrutura dental perdida. Restaurar a LCNC profunda de um pré-molar com um núcleo de resina composta, antes da moldagem para faceta cerâmica, apresentou melhor comportamento mecânico em MEF e menos desgaste dental. Para a LCNC de $1 \mathrm{~mm}$, biselar a lesão promoveu boa distribuição de tensões, um desgaste menos invasivo e um procedimento clínico mais fácil, já que não envolveu um procedimento restaurador prévio. Pode-se concluir que a decisão restauradora para pré-molares com LCNC que irão receber facetas deve considerar o comportamento biomecânico do conjunto e, principalmente, o desgaste de estrutura dental necessário. Para o caso apresentado, após 2 anos de acompanhamento, nenhuma mudança foi observada, indicando que a causa das lesões foi eliminada, e que o tratamento foi efetivo, ao menos no curto prazo. Para MEF, restaurar a LCNC antes da moldagem para facetas, apresentou melhor comportamento mecânico e menor desgaste dentário. Para a LCNC de 1,0 mm, fazer o bisel na margem da lesão levou aos mesmos bons resultados.

PALAVRAS-CHAVE: Desgaste dos dentes. Facetas dentárias. Análise de elementos finitos.

\section{REFERENCES}

ARCHANGELO, C. M.; ROCHA, E. P.; ANCHIETA, R. B.; MARTIN, M. JR.; FREITAS, A. C. JR.; KO, C. C.; CATTANEO, P. M. Influence of buccal cusp reduction when using porcelain laminate veneers in premolars. A comparative study using 3-D finite element analysis. Journal of Prosthodontic Research, Amsterdam, v. 55, n. 4, p. 221-227, oct. 2011. https://doi.org/10.1016/j.jpor.2011.02.005

ARIF, R.; DENNISON, J. B.; GARCIA, D.; YAMAN, P. Retrospective evaluation of the clinical performance and longevity of porcelain laminate veneers 7 to 14 years after cementation. Journal of Prosthetic Dentistry, St. Louis, v. 122, n. 1, p. 31-37, jul. 2019. https://doi.org/10.1016/j.prosdent.2018.09.007

CALAMIA, J. R.; CALAMIA, C. S. Porcelain laminate veneers: reasons for 25 years of success. Dental Clinics of North America, Philadelphia, v. 51, n. 2, p. 399-417, apr. 2007.

https://doi.org/10.1016/j.cden.2007.03.008

CARTER, D. R.; HAYES, W. C. The compressive behavior of bone as a two-phase porous structure. The Journal of Bone and Joint Surgery. American volume, Boston, v. 59, n. 7, p. 954-962, oct. 1977. https://doi.org/10.2106/00004623-197759070-00021

CESARIO, V. A. JR.; LATTA, G. H. JR. Relationship between the mesiodistal width of the maxillary central incisor and interpupillary distance. Journal of Prosthetic Dentistry, St. Lousis, v. 52, n. 5, p. 641-643, nov. 1984. https://doi.org/10.1016/0022-3913(84)90133-1

CHEE, B.; RICKMAN, L. J.; SATTERTHWAITE, J. D. Adhesives for the restoration of non- carious cervical lesions: a systematic review. Journal of Dentistry, Bristol, v.40, n.6, p.443-452, jun. 2012. https://doi.org/10.1016/j.jdent.2012.02.007

CIEPLIK, F.; SCHOLZ, K. J.; TABENSKI, I.; MAY, S.; HILLER, K. A.; SCHMALZ, G.; BUCHALLA, W.; FEDERLIN, M. Flowable composites for restoration of non-carious cervical lesions: Results after five years.

Dental Materials, Kidlington, v. 33, n. 12, p. e428-e437, dec. 2017.

https://doi.org/10.1016/j.dental.2017.09.012 
DA SILVA GONÇALVES, D.; CURA, M.; CEBALLOS, L.; FUENTES, M. V. Influence of proximal box elevation on bond strength of composite inlays. Clin Oral Investigations, Berlin, v. 21, n. 1, p. 247-254, jan. 2017. https://doi.org/10.1007/s00784-016-1782-7

D'ARCANGELO, C.; DE ANGELIS, F.; VADINI, M.; D'AMARIO, M. Clinical evaluation on porcelain laminate veneers bonded with light-cured composite: results up to 7 years. Clinical Oral Investigations, Berlin, v. 16, n. 4, p. 1071-1079, aug. 2012. https://doi.org/10.1007/s00784-011-0593-0

DAUDT, E.; LOPES, G. C.; VIEIRA, L. C. Does operatory field isolation influence the performance of direct adhesive restorations? Journal of Adhesive Dentistry, Berlin, v. 15, n. 1, p. 27-32, feb. 2013.

DECURCIO, R. A.; CARDOSO, P. C.; MAGALHAES, A. P. R.; MEDEIROS, E. A harmonious smile with minimal biological costs. Journal of Cosmetic Dentistry, Madison, v. 31, n. 2, p. 24-34, 2015.

DEMARCO, F. F.; COLlARES, K.; CORREA, M. B.; CENCI, M. S.; MORAES, R. R.; OPDAM, N. J. Should my composite restorations last forever? Why are they failing? Brazilian Oral Research, São Paulo, v. 31, n. 1, p. e56, aug. 2017. https://doi.org/10.1590/1807-3107bor-2017.vol31.0056

ERASLAN, O.; AYKENT, F.; YÜCEL, M. T.; AKMAN, S. The finite element analysis of the effect of ferrule height on stress distribution at post-and-core-restored all-ceramic anterior crowns. Clinical Oral Investigations, Berlin, v. 13, n. 2, p. 223-227, jun. 2009. https://doi.org/10.1007/s00784-008-0217-5

FERRACANE, J. L. Resin composite--state of the art. Dental Materials, Kidlington, v. 27, n. 1, p. 29-38, jan. 2011. https://doi.org/10.1016/j.dental.2010.10.020

FRON, H.; VERGNES, J. N.; MOUSSALLY, C.; CAZIER, S.; SIMON, A. L.; CHIEZE, J. B.; SAVARD, G.; TIRLET, G.; ATTAL, J. P. Effectiveness of a new one-step self-etch adhesive in the restoration of non- carious cervical lesions: 2-year results of a randomized controlled practice- based study. Dental Materials, Kidlington, v. 27, n. 3, p. 304-312, mar. 2011. https://doi.org/10.1016/j.dental.2010.11.006

GRESNIGT, M.; ÖZCAN, M.; MUIS, M.; KALK; W. Bonding of glass ceramic and indirect composite to nonaged and aged resin composite. Journal of Adhesive Dentistry, Berlin, v. 14, n. 1, p. 59-68, feb. 2012.

GRIPPO, J. O.; SIMRING, M.; COLEMAN, T. A. Abfraction, abrasion, biocorrosion, and the enigma of noncarious cervical lesions: A 20-year perspective. Journal of Esthetic and Restorative Dentistry, London, v. 24 , n. 1, p. 10-23, feb. 2012. https://doi.org/10.1111/j.1708-8240.2011.00487.x

JAKUPOVIC, S.; CERJAKOVIC, E.; TOPCIC, A.; AJANOVIC, M.; PRCIC, A. K.; VUKOVIC, A. Analysis of the Abfraction Lesions Formation Mechanism by the Finite Element Method. Acta Informatica Medica, Sarajevo, v. 22, n. 4, p. 241-245, aug. 2014. https://doi.org/10.5455/aim.2014.22.241-245

KIM, S. Y.; LEE, K. W.; SEONG, S. R.; LEE, M. A.; LEE, I. B.; SON, H. H.; KIM, H. Y.; OH, M. H.; CHO, B. H. Two-year clinical effectiveness of adhesives and retention form on resin composite restorations of noncarious cervical lesions. Operative Dentistry, Seatle, v. 34, n. 5, p. 507- 515, sep-oct. 2009.

https://doi.org/10.2341/08-006C

LOGUERCIO, A. D.; LUQUE-MARTINEZ, I.; LISBOA, A. H.; HIGASHI, C.; QUEIROZ, V. A.; REGO, R. O.; REIS, A. L. Influence of Isolation Method of the Operative Field on Gingival Damage, Patients' Preference, and Restoration Retention in Noncarious Cervical Lesions. Operative Dentistry, Seatle, v. 40, n. 6, p. 581593, nov-dec. 2015. https://doi.org/10.2341/14-089-C

MACHADO, A. C.; SOARES, C. J.; REIS, B. R.; BICALHO, A. A.; RAPOSO, L.; SOARES, P. V. Stressstrain Analysis of Premolars With Non-carious Cervical Lesions: Influence of Restorative Material, Loading Direction and Mechanical Fatigue. Operative Dentistry, Seatle, v. 42, n. 3, p. 253-265, may/jun. 2017. https://doi.org/10.2341/14-195-L 
MAGALHÃES, A. P. R.; DECURCIO, R. A.; OJEDA, G. P. D.; TEIXEIRA, T. R.; CARDOSO, P. C. Does Post-etching Cleaning Influence Bond Strength of Lithium Disilicate Laminate Veneers? Compendium of Continuing Education in Dentistry, Jamesburg, v. 38, n. 5, p. e9-e12, may. 2017.

MCCABE, J. F.; WALLS, A. W. G. Applied Dental Materials. 9. ed., Hong Kong: Blackwell Publishing Ltda, 2008. 303p.

MIURA, J.; MAEDA, Y.; NAKAI, H.; ZAKO, M. Multiscale analysis of stress distribution in teeth under applied forces. Dental Materials, Kidlington, v. 25, n. 1, p. 67-73, jan. 2009.

https://doi.org/10.1016/j.dental.2008.04.015

OGINNI, A. O.; ADELEKE, A. A. Comparison of pattern of failure of resin composite restorations in noncarious cervical lesions with and without occlusal wear facets. Journal of Dentistry, Bristol, v. 42, n. 7, p. 824-830, jul. 2014. https://doi.org/10.1016/j.jdent.2014.04.003

PERDIGÃO, J.; KOSE, C.; MENA-SERRANO, A. P.; DE PAULA, E. A.; TAY, L. Y.; REIS, A.; LOGUERCIO, A. D. New Universal Simplified Adhesive: 18-Month Clinical Evaluation. Operative Dentistry, Seatle, v. 39, n. 2, p.113-127, mar-apr. 2014. https://doi.org/10.2341/13-045-C

POIATE, I. A. V. P.; VASCONCELLOS, A. B.; POIATE JUNIOR, E.; DIAS, K. R. Stress distribution in the cervical region of an upper central incisor in a 3D finite element model. Brazilian Oral Research, São Paulo, v. 23, n. 2, p.161-168, apr-jun. 2009. https://doi.org/10.1590/S1806-83242009000200012

POLAT, S.; CEBE, F.; TUNÇDEMIR, A.; ÖZTÜRK, C.; ÜŞÜMEZ, A. Evaluation of the bond strength between aged composite cores and luting agent. Journal of Advanced Prosthodontics, Seoul, v. 7, n. 2, p. 108-114, apr. 2015. https://doi.org/10.4047/jap.2015.7.2.108

REES, J. S.; HAMMADEH, M. Undermining of enamel as a mechanism of abfraction lesion formation: a finite element study. European Journal of Oral Science, Copenhagen, v. 112, n. 4, p. 347- 352, aug. 2004. https://doi.org/10.1111/j.1600-0722.2004.00143.x

REIS, A.; SOARES, P. V.; DE GEUS, J.; LOGUERCIO, A. D. Clinical Performance of Root Surface Restorations. Monographs in Oral Science, Basel, v. 26, p. 115-124, 2017. https://doi.org/10.1159/000479353

RUBIN, C.; KRISHNAMURTHY, N.; CAPILOUTO, E.; YI, H. Stress analysis of the human tooth using a three-dimensional finite element model. Journal of Dental Research, Chicago, v. 62, n. 2, p. 82-86, feb. 1983. https://doi.org/10.1177/00220345830620021701

SAWLANI, K.; LAWSON, N. C.; BURGESS, J. O.; LEMONS, J. E.; KINDERKNECHT, K. E.; GIVAN, D. A.; RAMP, L. Factors influencing the progression of noncarious cervical lesions: A 5-year prospective clinical evaluation. Journal of Prosthetic Dentistry, St. Louis, v. 115, n. 5, p. 571-577, may. 2016. https://doi.org/10.1016/j.prosdent.2015.10.021

SHINYA, A.; YOKOYAMA, D.; LASSILA, L. V.; SHINYA, A.; VALLITTU, P. K. Three-dimensional finite element analysis of metal and FRC adhesive fixed dental prostheses. Journal of Adhesive Dentistry, Berlin, v. 10, n. 5, p. 365-371, oct. 2008.

SOARES, P. V.; SANTOS-FILHO, P. C.; GOMIDE, H. A.; ARAUJO, C. A.; MARTINS, L. R.; SOARES, C. J. Influence of restorative technique on the biomechanical behavior of endodontically treated maxillary premolars. Part II: strain measurement and stress distribution. Journal of Prosthetic Dentistry, St. Louis, v. 99, n. 2, p.114-122, feb. 2008. https://doi.org/10.1016/S0022-3913(08)60027-X 
SOARES, C. J.; VERSLUIS A.; VALDIVIA, A. D. C. M.; BICALHO, A. A.; VERÍSSIMO, C.; FERREIRA BARRETO, B. C. F.; ROSCOE, M. G. Finite element analysis in dentistry-improving the quality of oral health care. In: MORATAL, D. Finite Element Analysis- From Biomedical Applications to Industrial Developments. Rijeka: InTech, 2012. chapter 2, p. 25-56. https://doi.org/10.5772/37353

SOARES, P. V.; SOUZA, L. V.; VERÍSSIMO, C.; ZEOLA, L. F.; PEREIRA, A. G.; SANTOS-FILHO, P. C.; FERNANDES-NETO, A. J. Effect of root morphology on biomechanical behaviour of premolars associated with abfraction lesions and different loading types. Journal of Oral Rehabilitation, Oxford, v. 4, n. 2, p. 108114, feb. 2014a. https://doi.org/10.1111/joor.12113

SOARES, P. V.; SPINI, P. H. R.; CARVALHO, V. F.; SOUZA, P. G.; GONZAGA, R. C.; TOLENTINO, A. B.; MACHADO, A. C. Esthetic rehabilitation with laminated ceramic veneers reinforced by lithium disilicate. Quintessence International, Berlin, v. 45, n. 2, p. 129-133, feb. 2014b.

SOARES, P.V.; MACHADO, A.C.; ZEOLA, L.F.; SOUZA, P. G.; GALVÃO, A. M.; MONTES, T. C.; PEREIRA, A. G.; REIS, B. R.; COLEMAN, T. A.; GRIPPO, J. O. Loading and composite restoration assessment of various non-carious cervical lesions morphologies-3D finite element analysis. Australian Dental Journal, Sydney, v. 60, n. 3, p.309-316, sep. 2015. https://doi.org/10.1111/adj.12233

SOARES, P. V.; GRIPPO, J. O. Noncarious Cervical Lesions and Cervical Dentin Hypersensitivity: Etiology, Diagnosis, and Treatment. 1. ed. Chicago: Quintessence Publishing International, 2017. 208p.

SOUZA, P. G.; MACHADO, A. C.; PEREIRA, A. G.; TEIXEIRA, R. R.; ESPÍNDOLA, F. S.; SOARES, P. V. The dentin chemical degradation and saliva roles on Noncarious Cervical Lesions - literature review. Revista Odonto Ciência - Journal of Dental Science, Porto Alegre, v. 32, n. 4, p. 199-203, 2017.

https://doi.org/10.15448/1980-6523.2017.4.28634

TANAKA, M.; NAITO, T.; YOKOTA, M.; KOHNO, M. Finite element analysis of the possible mechanism of cervical lesion formation by occlusal force. Journal of Oral Rehabilitation, Oxford, v. 30, n.1, p.60-67, jan. 2003. https://doi.org/10.1046/j.1365-2842.2003.00959.x

TEIXEIRA, D. N. R.; ZEOLA, L. F.; MACHADO, A. C.; GOMES, R. R.; SOUZA, P. G.; MENDES, D. C.; SOARES, P. V. Relationship between noncarious cervical lesions, cervical dentin hypersensitivity, gingival recession, and associated risk factors: A cross-sectional study. Journal of Dentistry, Bristol, v. 76, p. 93-97, sep. 2018. https://doi.org/10.1016/j.jdent.2018.06.017

VERSLUIS, A.; TANTBIROJN, D. Relationship between shrinkage and stress. In: DASKALAKI, A. (Ed). Dental computing and applications: advanced techniques for clinical dentistry. 1. ed. New York: IGI Global, 2009. p. 45-64. https://doi.org/10.4018/978-1-60566-292-3.ch003

ZEOLA, L. F.; PEREIRA, F. A.; MACHADO, A. C.; REIS, B. R.; KAIDONIS, J.; XIE, Z.; TOWNSEND, G. C.; RANJITKAR, S.; SOARES, P. V. Effects of non-carious cervical lesion size, occlusal loading and restoration on biomechanical behaviour of premolar teeth. Australian Dental Journal, Sydney, v. 61, n. 4, p. 408-417, dec. 2016. https://doi.org/10.1111/adj.12391 